Author version: Mar. Pet. Geol., vol.58A; 2014; 368-381

\title{
Effect of thermal non-equilibrium, seafloor topography and fluid advection on BSR-derived geothermal gradient
}

\author{
R. Mandal ${ }^{1}$, P. Dewangan ${ }^{1 \star}$, T. Ramprasad $^{1}$, B.J.P Kumar ${ }^{2}$, K. Vishwanath $^{2}$ \\ ${ }^{1}$ CSIR-National Institute of Oceanography, Goa - India 403004 \\ ${ }^{2}$ Directorate General of Hydrocarbons, Noida, U.P - India 201301 \\ *corresponding author: pdewangan@nio.org
}

\begin{abstract}
The seafloor and bottom simulating reflectors (BSRs) are interpreted from the 3D seismic data acquired in Krishna-Godavari (KG) offshore basin in the vicinity of sites drilled/cored during National Gas Hydrate Program (NGHP) Expedition-01. The shallow structures such as inner toe-thrust fault system, regional and local linear fault systems and mass transport deposits are inferred from attributes of seafloor time structure as well as from the seismic profiles. The geothermal gradient is estimated from the depths and temperatures of the seafloor and the BSR. The temperature at the BSR depth is estimated from the methane hydrate and seawater salinity phase boundary assuming that the BSR represents the base of the gas hydrate stability zone. The spatial variations in geothermal gradient (GTG) show a strong correlation with seafloor topography in the KG basin. The GTG decreases by $\sim 13-$ $30 \%$ over the topographic mounds formed due to inner toe-thrust faults and recent mass transport deposits. The GTG decreases by only 5-10\% over the mounds, likely due to defocusing of heat flux based on one-dimensional topographic modeling. Hence, the GTG perturbation due to topography alone cannot explain the observed GTG anomaly. The temperature profile beneath these mounds may not be in equilibrium with the surroundings either due to the recent upliftment of sediments along the inner toe-thrust faults or rapid deposition of sediments due to slumping/sliding. In contrast, an increase in GTG by $10-15 \%$ is observed in the vicinity of major fault systems. We presume that the likely mechanism for the increase in GTG is fluid advection from a deeper part of the basin. A detailed thermal modeling involving the effect of surface topography, high sedimentation rates, fluid advection and sediment thickening due to tectonics is required to understand the thermal profile in KG offshore basin.
\end{abstract}




\section{Introduction}

Gas-hydrate is an ice-like, crystalline solid in which methane and other lighter hydrocarbon molecules are trapped inside the cages of water molecules and stable under high pressures and low temperatures in Polar Regions (onshore and offshore permafrost) and sediments of continental margins (Kvenvolden et al., 1993; Sloan, 1990). Globally, it occurs as massive, nodular, laminar and disseminated form within the inter-granular pore spaces (Brooks et al., 1986). Enormous amount of methane or other lighter hydrocarbon gases are stored as gas hydrate within the gas hydrate stability zone (GHSZ); free gas may exists below the GHSZ which adds to the global storage of hydrocarbon gases. This potentiality of hydrocarbon gas prompted scientific community to study the natural gas hydrates as an alternative energy resource. It is also believed to be an important factor for global climate change, marine geohazard (Kvenvolden, 1993), and drilling hazard for deep-waters hydrocarbon exploration (Nimblett et al., 2005).

In seismic sections, gas hydrate is identified by an anomalous reflector known as Bottom Simulating Reflector (BSR) which mimics with the seafloor, crosscuts geological layers and its polarity is reversed with respect to that of seafloor. BSR acts as a boundary between the overlying gas hydrate bearing sediments and underlying free gas bearing sediments (Hyndman and Spence, 1992; Shipley et al., 1979). The presence of gas hydrate increases the seismic velocity while free gas decreases the velocity thereby creating a strong negative impedance contrast across the GHSZ (Helgerud et al., 1999). In addition to BSR, other geological structures such as pockmarks, gas chimneys and mud mounds are considered as good indicators for the presence of methane in the subsurface sediments (Holbrook et al., 1996; Ramana et al., 2006; Riedel et al., 2006).

The thickness of GHSZ depends on geothermal gradient (GTG), pressure, salinity and phase curve of methane and seawater (Kvenvolden, 1993). The theoretical GHSZ thickness maps of the Indian continental margins (NIO 1997; Sain et al., 2011) have shown Mahanadi, Krishna-Godavari $(K G)$, Kerala-Konkan (KK), Cauvery and Saurashtra basins to have potential for the occurrence of gas hydrate. The Indian National Gas Hydrate Program (NGHP) Expedition-01 confirmed the presence of gas hydrate in KG offshore, Mahanadi and Andaman basins (Collett et al. 2008). The thickness of GHSZ can also be estimated from the seismic data, and it can be used to understand the regional variation in GTG assuming negligible effect of the variations in pressure, salinity and composition of hydrocarbon gases. The primary factors which can affect the GTG are seafloor topography (Lachenbruch, 1968), migrating of deeper, warmer fluid through the existing faults/fractures network (Cooper and Hart, 2002; Dewangan et al., 2011; Minshull and White, 1989; Ruppel and Kinoshita, 2000; Ruppel et al., 2005) and sediment thickening due to local tectonics (Wang et al., 1993). The 
BSR-derived GTG has been studied in KG offshore basin primarily from sparsely spaced 2D seismic data, and the effect of seafloor topography (Shankar and Riedel, 2010) and fluid advection in the vicinity of Site NGHP-01-10 (Dewangan et al., 2011) have been reported. However, a systematic study of the variation in GTG and its relationship with shallow depositional environment has not been established. In the present study, we re-processed and interpreted the 3D seismic data covering the drilling/coring sites of NGHP-Expedition-01 and established the shallow depositional environment in KG offshore basin. This is the first report of 3D seismic data from a well studied gas hydrate rich margin. The regional variation in GTG is estimated from the depths of seafloor and BSR obtained from the three-dimensional seismic data. We attempt to understand the observed variations in GTG based on the shallow depositional environment in KG offshore basin.

\section{Geological Setting}

The study area is located in the continental slope of KG basin, Eastern Continental Margin of India (ECMI). The evolution of ECMI initiated $~ 130 \mathrm{Ma}$ when India separated from its conjugate Australia/Antarctica, eastern Gondwanaland (Johnson et al., 1980; Powell et al., 1988). The KG basin and its adjacent two basins, namely Mahanadi and Cauvery basins also evolved in ECMI as a consequence of rifting and drifting. KG basin is one of the most promising petroliferous basin in India, which occupies an area of 28,000 km² onland and 145,000 km² offshore (Bastia and Nayak, 2006; Rao, 2001). The sediment thickness of KG basin varies from 3 to $5 \mathrm{~km}$ in the onshore region and $\sim 8 \mathrm{~km}$ in the offshore region (Prabhakar and Zutshi, 1993). Krishna and Godavari river systems discharge bulk of sediment load in KG offshore basin. The basin contains thick sequences of sediments with several cycles of deposition ranging in age from Late Carboniferous to Holocene (Rao, 2001). It has been noticed that during Neogene period, sedimentation rate increased drastically after the upliftment and erosion of Himalayas (Subrahmanyam and Chand, 2006). The KG basin geomorphology is very divergent and contain different kind of geological structures such as channel-levee system, sliding/slumping, diapirs, mass transport deposits, gas chimney, bathymetric mounds (Ramana et al., 2009; Dewangan et al., 2010; Ramprasad et al., 2011; Riedel et al., 2011).

One of the characteristic features of KG basin is shale tectonism. Due to the huge load of sediments deposited by Krishna and Godavari rivers, KG basin shows deformation structures such as Paleogene and Neogene extensional growth faults in the continental shelf and upper slope regions and toe-thrust in deep offshore regions similar to those observed in gravity-driven shale tectonism (Bastia, 2006; Damuth, 1994; Gupta, 2006; Rao and Mani, 1993; Rao, 1993). The shale tectonism occurs due to the movement of overpressured Miocene and Pliocene shale strata (Basu, 1990; Rao and Mani, 1993; Rao, 1993) and leads to the formation of prominent topographic features and fault/fracture 
network. These faults/fracture network acts as the most favorable pathways for fluid migration (Dewangan et al., 2010) which may reposition the BSR and sometimes obliterate the same. The fluids carrying hydrothermal pore fluids, brines and free gas or warm water upon reaching the seafloor may results in the formation of pockmarks, craters or mud mounds (Hovland and Judd 1988). Several pockmarks, gas chimneys and mud mounds have been reported in KG offshore basin based on the interpretation of high resolution geophysical data (Ramana et al., 2006). Geological and geochemical analysis of a short core ( $30 \mathrm{~m})$ acquired onboard RV Marion Dufresne in the vicinity of NGHP-01-10 showed a paleo-expulsion event confirming the expulsion of methane rich fluids through fault system (Mazumdar et al., 2009). The expulsion of the fluids beyond the GHSZ may destabilize the upper slope sediment, and initiate slumping/sliding which leads to mass transport deposits in offshore regions (Bugge et al. 1987; Ramprasad et al., 2011).

\section{Data and processing}

The map of the available geophysical data such as multibeam bathymetry (Ramana et al., 2008) and the sites drilled/cored during NGHP-Expedition-01 (Collett et al., 2008) in KG offshore basin is shown in Figure 1. In the present study, 3D multi-channel seismics (MCS) data acquired by Oil and Natural Gas Commission Ltd. (ONGC) in KG offshore basin (Fig. 1) have been re-processed and interpreted to understand the shallow depositional environment and estimate the regional variation in GTG. The seismic data were acquired in 2002 onboard M/V Western Monarch using five receiver cables and dual source air-gun. A $2750 \mathrm{cu}$. in. air gun was fired every $50 \mathrm{~m}$ and five 5-km long cables (each 200 channels with $25 \mathrm{~m}$ group interval) were deployed to record the seismic data. The separation between the cables is $\sim 200 \mathrm{~m}$. The 3D seismic volume covers an area of $1940 \mathrm{~km}^{2}$ in the KG offshore basin (Fig.1). The 3D seismic data is binned along the inline and crossline directions and their spacing are $50 \mathrm{~m}$ and $12.5 \mathrm{~m}$, respectively. The Root-Mean Squared (RMS) velocities are obtained at a grid of $500 \mathrm{~m} \times 500 \mathrm{~m}$ using conventional semblance analysis. In order to account for conflicting dips between the geological layers and BSR, common-offset F-K Dip-Move out (DMO) was incorporated during seismic data processing, and refined velocities have been estimated after DMO correction (Liner, 1990). A brute stack seismic section was obtained by stacking the seismic data after applying normalmoveout (NMO) correction. A Stolt 3D migration scheme was adopted for post-stack time migration (PSTM) (Stolt, 1978). The processing of raw 3D seismic data was performed using ProMAX 3D software on HP Z800 workstation.

The seafloor and BSR reflections were identified and picked in the processed 3D PSTM volume using SeisWorks software on HP Z800 workstation. The BSRs were picked mainly along inlines, but were cross checked in the crosslines seismic section for continuity, and BSR have been observed on 
an area of $\sim 700 \mathrm{~km}^{2}$. The seismic data exhibits a variety of geological structures such as faults, bathymetric mounds, toe-thrust, slope basin and slumping/sliding. The picking of BSR as maximum positive amplitude (seafloor amplitude is negative in the present study) was challenging in the seismic section due to dipping reflectors, slope basin and mounds. Therefore, we choose to pick the BSR as zero-amplitude transition from positive-to-negative amplitudes, and likewise the seafloor is also picked as zero-amplitude transition from negative-to-positive amplitudes. During picking of BSR, criteria of crosscutting of geological layers and mimicking the seafloor topography has been used as a measure of quality control. In the zones where BSRs were difficult to pick on the seismic sections, the picking was carried out using the phase attribute of seismic section.

The seafloor and BSR traveltimes were converted to depth using the corresponding RMS velocities. The seafloor temperature is estimated using the available CTD data in the study area. The pressure at the BSR depth is assumed to be equal to the hydrostatic pressure. Assuming that the pressure at the depth of BSR corresponds to the pressure at the transition between the hydrate and free gas, the temperature at the BSR depth is calculated from the phase curve of methane and standard seawater (Miles, 1995).The GTG is estimated from the depths and temperatures of the seafloor and the BSR using the equation,

$$
G T G=\frac{\left(T_{b s r}-T_{s f}\right)}{\left(Z_{b s r}-Z_{s f}\right)},
$$

where, $Z$ and $T$ represent the depth and temperature, respectively; the subscripts ' $b s r$ ' and 'sf' refer to BSR and seafloor, respectively. The heat flow $(q)$ was calculated by multiplying GTG with the average thermal conductivity $\left(K_{\text {avg }}=0.82 \mathrm{~W} / \mathrm{mK}\right.$ ) of the sediment (Collett et al., 2008) as,

$q=k_{\text {avg }} \times G T G$

All the maps are prepared using the public domain software, Generic Mapping Tools (GMT software: Wessel and Smith, 2013).

\section{Results}

The bathymetry data (Fig. 1; Ramana et al., 2008) shows major morphological features such as the sedimentary ridges $\left(\mathrm{SR}_{1}\right.$ and $\left.\mathrm{SR}_{2}\right)$ in the southeastern and southwestern parts of the study area, a couple of closely spaced mounds $\left(\mathrm{M}_{1}\right.$ and $\left.\mathrm{M}_{2}\right)$ are observed in the southwestern part and are associated with steep seafloor gradient, an elliptical shaped mound $\left(M_{3}\right)$ with its major axis extending SW-NE direction is seen abutting a topographic mound $\left(\mathrm{M}_{4}\right)$ in the vicinity of the deltafront and an NW$\mathrm{SE}$ trending channel is observed on the west of the sedimentary ridge $\left(\mathrm{SR}_{1}\right)$ in the southwestern corner 
of the study area. The topographic features such as $\mathrm{SR}_{1}$ and $\mathrm{SR}_{2}$ are formed due to toe-thrust (Dewangan et al., 2010) and will be referred as outer toe-thrust in the present study.

The seafloor reflection has been identified on 3D PSTM data, and a seafloor time map is presented in Fig. 2a.The seafloor time is used to produce seismic dip and azimuth attributes maps (Fig. $2 \mathrm{~b}$ and Fig. 3a). The interpreted map is shown in Figure 3b. The dip and azimuth maps depict a toethrust-like feature at the edge of the delta front in the northeastern part of the study area. This feature is demarcated by a curvilinear fault (CF) and will be referred as inner toe-thrust (Fig. 3b). The geometrical configuration of inner toe-thrust is similar to that of the outer toe-thrust. A tongue-like feature in the north towards west (MTD-1) and a broad low relief feature (MTD-2) in central part in the north are observed which are interpreted as mass transport deposits (MTDs) (after Ramprasad, et al., 2011). In the central part of the area in the south, a lobe-like structure (MTD-3) is observed, and on the west of MTD-1 towards south another lobe structure (MTD-4) is observed. A low relief MTD (MTD-5) is observed between MTD-1 and MTD-2. Several small scale fault-like features (F) trending in SW-NE direction are observed over the elliptical mound $\left(M_{3}\right)$ in the mid slope region. A distinct fault $F 1$ is observed in N-S direction on the western edge of MTD-4. A ridge-like feature $\left(\mathrm{SR}_{1}\right)$ trending NW-SE is observed as a continuation of outer toe-thrust in the southwestern part of the area which abuts fault F2. Towards west of the area, two more faults F3 and F4 are interpreted which are parallel to the faults F1 and F2. On the eastern flank of the ridge $\left(\mathrm{SR}_{1}\right)$, another fault $\mathrm{F} 5$ is observed running in the NW-SE direction. Another major fault F6 is observed in E-W direction intersecting fault F1 at the southern edge of the MTD-4.

Twelve representative inline seismic profiles (Figs. 4A to $4 \mathrm{~L}$ ) have been selected to explain the characteristics of the bottom simulating reflections (BSRs), and the subsurface structures associated with shale tectonism/neotectonism and regional fault systems. The seismic sections are selected based on their potential to explain different geological structures and their influence on GTG variation. In general, BSR deepens towards the deeper part of the area nearly mimicking the seafloor. Line no. $A A^{\prime}$ (Fig. 4A) transects east of the elliptical mound $M_{3}$ and crossing over Site NGHP-01-14. The seafloor in the shallower portion is flat between traces 1 and 320; it dips gently up to trace 460 and further becomes flat. A domal structure is observed in the middle of the section below the GHSZ and the BSR is continuous till the end of the section. The curvilinear fault (CF) associated with inner toe-thrust have been observed towards the southern edge of this dome. GTG varies between 33 and $44{ }^{\circ} \mathrm{C} / \mathrm{km}$ along this seismic profile. In shallow portion, GTG is low $\left(33^{\circ} \mathrm{C} / \mathrm{km}\right)$ and it fluctuates between 39 and 42 ${ }^{\circ} \mathrm{C} / \mathrm{km}$ towards top of the dome and reaches to about $39^{\circ} \mathrm{C} / \mathrm{km}$ at the end of line. The GTG measured at Site NGHP-01-14 is close to $38 \pm 2{ }^{\circ} \mathrm{C} / \mathrm{km}$ (Collett et al., 2008) which is close to the estimated GTG at 
this site.

The seismic profiles BB', CC', DD' and EE' (Fig. 4B, 4C, 4D and 4E) transect the elliptical mound $M_{3}$ and the mound in the vicinity of delta front $\left(M_{4}\right)$. The seafloor reflection depicts a step like configuration in the shallow part, a domal shape in the middle, synclinal shape in the midslope and gets shallow towards the end of the seismic section. The GHSZ increases from the shallow to deep except between the traces 50 and 250 (Line BB') where the seafloor appears to be disturbed due to the fault extending from the subsurface to the seafloor. The CF system is associated with the step like features suggesting newly evolved toe-thrust system. The fault system $F$ over the mound $M_{3}$ is clearly observed in the seismic section (Line DD'; Fig. 4D). The variations of the GHSZ are reflected in the GTG profile; low GTG is associated with thicker GHSZ and high GTG with thinner GHSZ. In general, the GTG shows large variation $\left(30-45^{\circ} \mathrm{C} / \mathrm{km}\right)$ in the shallow part of the sections where the seafloor shows steplike variation, while it varies $\left(40-42^{\circ} \mathrm{C} / \mathrm{km}\right)$ gently in the deeper part. The central domal structure $\mathrm{M}_{3}$ depicts high GTG values ranging from $40-45^{\circ} \mathrm{C} / \mathrm{km}$ in the vicinity of fault system F (Line DD'; Fig. 4D). Line BB' transects over Site NGHP-01-05 and estimated high GTG $\left(45^{\circ} \mathrm{C} / \mathrm{km}\right)$ is close to the measured GTG $44 \pm 3^{\circ} \mathrm{C} / \mathrm{km}$ at this Site.

Line no. FF' (Fig. 4F) exhibits no major structures and the seafloor as well as BSR is gently dipping. This line is selected to represent the background GTG of the area which varies between 38 and $40{ }^{\circ} \mathrm{C} / \mathrm{km}$. Similarly, Line no. LL' (Fig. 4L) shows no subsurface structures, and the GTG values vary between 38 and $40{ }^{\circ} \mathrm{C} / \mathrm{km}$ representing the background GTG in the study area. Line no. GG' and $\mathrm{HH}^{\prime}$ (Figs. 4G and $4 \mathrm{H}$ ) are across the midslope basin, the seafloor is gently dipping, and the BSR is discernible throughout the basin. The GTG varies gently from $27^{\circ} \mathrm{C} / \mathrm{km}$ in the deeper part of the basin to $38^{\circ} \mathrm{C} / \mathrm{km}$ toward the top of the mound. Over the mound in southern part of the lines the GTG increases up to $41^{\circ} \mathrm{C} / \mathrm{km}$. Line no. GG' is passing near to Site NGHP-01-03. The GTG measure at Site NGHP-01-03 is $39 \pm 2{ }^{\circ} \mathrm{C} / \mathrm{km}$ (Collett et al., 2008) which is close to the estimated GTG at this site. In Line $\mathrm{HH}^{\prime}$, between traces 1 and 290, MTD-1 is observed in the seafloor reflection within the midslope basin, and depth to the BSR is not influenced by the increased thickness of the MTD leading to a sudden decrease in BSR-derived GTG to $25^{\circ} \mathrm{C} / \mathrm{km}$. Over the mound $\mathrm{M}_{1}$, the seafloor between traces 800 and 950 appears to be disturbed by the subsurface faults F6. The GTG value in the vicinity of the fault increases to $48^{\circ} \mathrm{C} / \mathrm{km}$.

Line no. II' and Line no. JJ' (Fig. $4 \mathrm{I}$ and 4J) transect MTD-4 between traces 200 and 800 and mound $M_{1}$ between traces 850 to 950 . BSR crosscuts different upward dipping subsurface geological layers. High amplitude reflections are identified below the BSR in the mound region probably related to the presence of free gas. In the MTD-4 zone, GTG varies between 30 and $38{ }^{\circ} \mathrm{C} / \mathrm{km}$ while it varies 
between 40 and $47^{\circ} \mathrm{C} / \mathrm{km}$ in the vicinity of faults F1 and F6 over the mound. Line $\mathrm{JJ}$ transect the Site NGHP-01-10, and the measured GTG at the site $45 \pm 3{ }^{\circ} \mathrm{C} / \mathrm{km}$ (Collett et al., 2008) is close to the estimated GTG.

Seafloor along the Line no. KK' (Fig. 4K) depicts a domal shape $\mathrm{M}_{2}$ in the middle of the section. BSR mimics the seafloor and crosscuts subsurface geological layers in the shallow part of the section. Some high amplitude subsurface layers have been identified below BSR between traces 200 and 500 probably associated with the free gas. In the beginning of the profile, GTG varies from $37^{\circ} \mathrm{C} / \mathrm{km}$ at trace 50 to $47^{\circ} \mathrm{C} / \mathrm{km}$ at trace 300 towards the south side of fault F2. It decreases to $38^{\circ} \mathrm{C} / \mathrm{km}$ over top of the mound $\mathrm{M}_{2}$ and further increases to $50^{\circ} \mathrm{C} / \mathrm{km}$ towards the north side of fault $\mathrm{F} 5$.

The spatial distribution of BSR traveltime is shown in Figure 5 illustrating the effect of subsurface geological structures on the BSR distribution map. The computed GTG and its interpretation are shown in Figures 6A and 6B, respectively. The background GTG of this region is assumed to be 39 ${ }^{\circ} \mathrm{C} / \mathrm{km}$. High GTG values $\left(45-50{ }^{\circ} \mathrm{C} / \mathrm{km}\right.$ ) are observed over the mounds $M_{1}$ and $M_{2}$ in the vicinity of regional faults $F 1, F 2, F 5$ and F6. A similar increase in GTG is observed over the mound $M_{3}$ associated with the fault system F. In contrast, low GTG values $\left(25-35^{\circ} \mathrm{C} / \mathrm{km}\right)$ are observed over the mound $\mathrm{M}_{4}$ formed due to inner toe-thrust in northeastern part of the study area. A low GTG $\left(\sim 25-30^{\circ} \mathrm{C} / \mathrm{km}\right)$ is also observed within the midslope basin which is filled with MTDs. In particular, significantly low GTG (<25 ${ }^{\circ} \mathrm{C} / \mathrm{km}$ ) is observed over the mounds MTD-1 towards middle to western part of the study area. Heat flow map can be computed from GTG values by multiplying it with a constant thermal conductivity of 0.82 W/mK and depicts similar features as that of GTG.

\section{Interpretation and Discussion}

\subsection{Shallow depositional environment in the Krishna-Godavari offshore basin}

The outer toe-thrust has led to the formation of bathymetric mounds $\left(M_{1}, M_{2}\right.$ and $\left.M_{3}\right)$ and sedimentary ridges $\left(\mathrm{SR}_{1}\right.$ and $\left.\mathrm{SR}_{2}\right)$ in the deep offshore $\mathrm{KG}$ basin (Dewangan et al., 2010). The analysis of seismic profiles (Figs. 4A-E) in the north-western part of the study area shows an occurrence of a similar, curvilinear fault system associated with inner toe-thrust which has upthrusted the sediments of upper continental margins to form a prominent bathymetric mound $\mathrm{M}_{4}$ (Fig. 1). The step-like texture of the bathymetry mound suggests that the inner toe-thrust system is younger, and the imprints of the individual faults are observed on the seafloor attribute map (Fig. 3b).

Large scale (> $12.5 \mathrm{~km}$ ) linear faults oriented in the NNW-SSE and ENE-WSW directions (Dewangan et al., 2011; Riedel et al., 2010) representing passive-margin tectonics are observed in dip/azimuth map of the seafloor (Figs 2 and 3) as well as on the seismic profiles (Figs. 4H-K). Several 
small scale co-linear faults $(<5 \mathrm{~km})$ are observed on the bathymetric mound $\mathrm{M}_{4}$ (Figs $\left.4 \mathrm{~B}-\mathrm{D}\right)$. We presume that these faults are related to the folding caused by compression tectonics.

The shale tectonism has also led to the formation of intra-slope basin which is filled with several mass transport deposits (MTDs). The origin of MTDs is related to the slumping/sliding of the upper slope sediments and some of the factors responsible for slope instability in KG offshore basins are high sediment influx, high sedimentation rate, steep seabed gradient and the migration of fluid through the regional fault systems (Ramprasad et al., 2011). Average thickness of these deposits varies with depth from $45 \mathrm{~m}$ in the upper slope sediment to $90 \mathrm{~m}$ in deeper offshore locations. A recent Holocene cover of $\sim 5 \mathrm{kyr}$ is observed over these MTDs indicating that these deposits are atleast $5 \mathrm{kyr}$ old (Mazumdar et al., 2009). Some MTDs are identified in KG basin based on the analysis bathymetry and high resolution seismic (HRS) data; many more MTDs (MTD-1-5) are identified within the intra-slope basin based on the analysis of dip/azimuth map of the seafloor (Figs. 2 and 3). The MTDs are also observed as elevated topographic features in the seismic profile (e.g., Fig. 4H).

\subsection{Spatial variability of BSR-derived geothermal gradient in KG offshore basin}

The background heat flow $(q)$ depends on the age of the crust $(\mathrm{t})$ and can be calculated using the formula of Stein and Stein (1994),

$$
q=48+96 \times e^{-0.0279 \times}
$$

Assuming an age of $\sim 130$ Ma using magnetic anomaly (Ramana et al., 1994), the background heat flow is calculated to be $\sim 50 \mathrm{~mW} / \mathrm{m}^{2}$. After correcting for the sedimentation rate, the background GTG is estimated to be of $36-40{ }^{\circ} \mathrm{C} / \mathrm{km}$ (Dewangan et al., 2011). In the study area, GTG shows strong correlation with the topographic features such as mounds/ridges formed due to shale tectonism or MTDs as well as with the fault system. A couple of representative seismic profiles (Fig. 4F between crosslines 500 and 850 and Fig. 4L between crosslines 200 and 600) are devoid of mounds and fault system, and they show a uniform GTG of $\sim 39^{\circ} \mathrm{C} / \mathrm{km}$ which is within the expected range of background GTG. Therefore, we have considered $39{ }^{\circ} \mathrm{C} / \mathrm{km}$ to be the background $\mathrm{GTG}$ in $\mathrm{KG}$ offshore basin. Assuming a mean thermal conductivity of $0.82 \mathrm{~W} / \mathrm{mK}$, the background heat flow is calculated to be $\sim 32$ $\mathrm{mW} / \mathrm{m}^{2}$.

The background heat flux may be perturbed due to the heat brought by fluid advection, focusing/defocusing of heat flux due to topography, tectonic thickening or the combination of these factors (Ganguly et al., 2000). Some of these factors are observed in KG offshore basin based on the analysis of sparse 2D seismic data. The migration of warm fluid through the fault systems have led to the increase in GTG by $15-20 \%$ in the vicinity of Site NGHP-01-10 (Dewangan et al., 2011). The 
defocusing effect of topography have led to the decrease in GTG by 3-4 \% in the vicinity of sedimentary ridges $\left(\mathrm{SR}_{1}\right.$ and $\mathrm{SR}_{2}$ ) (Shankar and Riedel, 2010). The combination of both these factors may lead to lower GTG at the top of the mound and higher GTG in the vicinity of the faults. In the present study, GTG is mapped in KG offshore basin using 3D seismic data. The GTG is largely influenced by the structural styles due to shale/neo tectonism, MTDs and fault systems which may lead to either increase or decrease in GTG as compared to the background GTG (Fig. 6). We attempt to understand the primary process responsible for the observed GTG pattern in KG offshore basin.

\subsubsection{Relationship between low GTG over mounds and inner toe-thrust}

The seismic lines across the mound $\mathrm{M}_{4}$ (Fig. 4B-D) show that inner toe-thrust ( $C F$ and associated faults) has uplifted the upper slope sediments onto the seafloor. In the vicinity of fault $\mathrm{CF}$, the GTG over the mound $\mathrm{M}_{4}$ is about $\sim 31-34{ }^{\circ} \mathrm{C} / \mathrm{km}$ which is lower by $13-20 \%$ as compared to the background GTG. It is known that the topography can affect the superficial geothermal gradient by focusing and defocusing of the background heat flux (Lachenbruch, 1968; Ganguly et al., 2000; Shankar and Riedel, 2010). Heat flux is defocused over the ridges leading to lower GTG while it is focused over the valley leading to higher GTG. The effect of topography on the superficial GTG can be modeled using the approximate solution of Lachenbruch (1968). Approximate 1D solution of the heat flow suggests that GTG can decrease by $\sim 8-10 \%$ for a maximum observed slope of $\sim 7^{\circ}$ which is about half of the observed decrease in GTG. In addition, the Lachenbruch's approximate solution was obtained at the seafloor and is applicable only for shallow heat flow probe measurements where the average height of the relief is larger than the depth of investigation. In the case of BSR-derived geothermal gradient, the GTG is estimated from a depth of few hundreds of meters which is often larger than the magnitude of smaller topographic mounds ( $-30-60 \mathrm{~m})$; therefore, it is expected that the effect of topography will be smoothened out for the BSR-derived GTG and the actual perturbation will be smaller than that predicted from the approximate solution. The two-dimensional time-dependent finite element thermal modeling of the Washington-Oregon toe-thrust faulting shows that the analytical solution of Lachenbruch (1968) may overestimate the GTG perturbation by a factor of three (Shi et al., 1988). We believe that the realistic estimate of BSR-derived GTG perturbation will be of the order of 3-5 $\%$ over the mound. Thus, the effect of topography cannot fully explain the observed decrease of GTG by $13-20 \%$. An alternative explanation for the observed GTG anomaly is that it may represent a transient phenomenon, and the temperatures below the mound are not in equilibrium with the surroundings. The inner toe-thrust is young and support the hypothesis of low GTG anomaly due to non-equilibrium thermal conditions over the mound $M_{4}$. Similar decrease in GTG due to tectonic 
thickening is also observed in the Cascadia margin off Vancouver Island (Hyndman et al., 1993; Wang et al., 1993) and Makran accretionary prism (Kaul et al., 2000).

\subsubsection{Low GTG within the midslope basin}

The GTG over the midslope basin (Fig. 4G-I) shows an abnormal decrease from $39{ }^{\circ} \mathrm{C} / \mathrm{km}$ at the flanks of the basin to $27^{\circ} \mathrm{C} / \mathrm{km}$ (a decrease of $\sim 31 \%$ ) at the center of the basin. Furthermore, GTG decreases rapidly by $\sim 17$ \% over MTD-1 (e.g. 4H between CDPs 150 and 300). The average slope within the midslope basin is less than $1^{\circ}$; therefore, the effect of topography (Lachenbruch, 1968) on GTG perturbation will be less than $4 \%$. Clearly, the topography effect is unable to explain the observed GTG anomaly within the basin as well as over the recent MTDs. We propose that the thermal profile over the basin is not in equilibrium with the surroundings due to rapid sedimentation related to MTDs. The ${ }^{14} \mathrm{C}$ dating of long core MD161/11 within the slope basin (Mazumdar et al., 2012; Ramprasad et al., 2011) shows rapidly deposited sediments at a depth of 14 meters below seafloor which may lead to the observed non-equilibrium thermal conditions in the study area.

\subsubsection{High GTG in the vicinity of fault system}

The sedimentary ridges $\left(\mathrm{SR}_{1}\right.$ and $\left.\mathrm{SR}_{2}\right)$ show low $\mathrm{GTG}$ anomaly which can be modeled using the defocusing effect of the topography (Figs. 8, 9, and 10 of Shankar and Riedel, 2013) indicating that the thermal profiles have attained equilibrium beneath these ridges. Interestingly, the GTG profile over the mound $M_{1}$ (Fig. 4J) show an increase from $39{ }^{\circ} \mathrm{C} / \mathrm{km}$ at the flank of the mound to $\sim 45^{\circ} \mathrm{C} / \mathrm{km}$ at the top of the mound in the vicinity of fault F1. Another mound $M_{2}$ (Fig. 4K) shows an increase in GTG up to $\sim 47-50{ }^{\circ} \mathrm{C} / \mathrm{km}$ in the vicinity of the faults $\mathrm{F} 2$ and $\mathrm{F} 5$. The GTG over the mound $\mathrm{M}_{2}$ is not anomalous and have a value of $\sim 39^{\circ} \mathrm{C} / \mathrm{km}$. Horst and graben structures are formed due to the fault system $\mathrm{F}$ over the mound $M_{3}$ (Fig. 4D), and it is reflected in GTG as high GTG over the graben. Overall, the spatial distribution of GTG (Fig. 6) shows high GTG over the major fault systems (F, F1, F2, F5 and F6) in the vicinity of mounds $\left(M_{1}, M_{2}\right.$, and $\left.M_{3}\right)$. The present study extends the findings of Dewangan et al. (2011) which reported a similar increase in GTG by $15-20 \%$ over the fault system F1 in the vicinity of mound $M_{1}$. Dewangan et al. (2011) analyzed several factors such as the effect of topography, variation in salinity at the base of the hydrate stability zone, thermal non-equilibrium of BSR and fluid/gas advection along the fault system and found that the likely explanation for the observed increase in GTG is due to focused fluid flow along the faults. The fluid advection rates were found to vary from 0.37 to $0.6 \mathrm{~mm} / \mathrm{yr}$ depending on the depth from which the fluid migrating is originating. Therefore, we attribute the increase in GTG in the vicinity of fault system to focused fluid flow from deeper horizon. Several studies elsewhere have shown similar increase in geothermal gradient due to focused fluid flow (Davis et al., 1990; De Batist et al., 2002; Mann and Kukowski, 1999; Minshull and White, 1989; Pecher et al., 2009; 
Zwart et al., 1996). A detailed thermal modeling involving the effect of surface topography, high sedimentation rates, fluid advection and sediment thickening due to tectonics is required to understand the thermal profiles in KG offshore basin.

\subsubsection{Sources of uncertainty in BSR-derived GTG}

The BSR-derived GTG may differ from the actual GTG due to the uncertainty in the gas composition of hydrate and salinity of pore fluid which leads to error in the calculation of phase curve, uncertainty in seafloor temperature, error incorporated during conversion of BSR time to depth due to inaccurate velocity or anisotropy and error in the identification of BSR in seismic profiles. The drilling/coring data during NGHP-Expedition-01 suggests the presence of methane hydrate in KG offshore basin with negligible concentration of higher hydrocarbons. The seafloor temperature is also well constrained from the available CTD data in KG offshore basin (Dewangan et al., 2011). The seismic profiles (Fig. 4) show well-demarcated BSRs in the study area. Therefore, the major source of uncertainty in the computation of GTG is velocity and salinity of the gas hydrate bearing sediments.

In general, the presence of gas hydrate increases the seismic velocity. If velocity perturbation is not accounted for the presence of gas hydrate, it will lead to underestimation of depth of the BSR and overestimation of GTG. In KG offshore basin, the RMS velocity (Vrms) obtained from conventional velocity analysis shows a well defined compaction trend (Fig. 7) and can be expressed as,

$V r m s=1501.24+0.05 \times$ dequh $+6.7025 \times 10^{-8} \times d a p t h^{2}-8.8046 \times 10^{-9} \times d a p t h^{8}$

where depth represents the depth below seafloor in meters and Vrms is expressed in $\mathrm{m} / \mathrm{s}$. The spread along the mean trend represents the variability in RMS velocity in KG offshore basin due to the changes in lithology, porosity, and composition of pore fluid and it increases with depth below seafloor. Assuming a mean BSR depth of $200 \mathrm{~m}$ at a water depth of $\sim 1100 \mathrm{~m}$, the RMS velocity (average $\sim 1514$ $\mathrm{m} / \mathrm{s}$ ) fluctuate from $1509-1520 \mathrm{~m} / \mathrm{s}$ primarily due to the presence of gas hydrates. Ignoring the presence of hydrate in the calculation of GTG will result in $\sim 0.5 \%$ error in the RMS velocity which will lead to $-0.55 \%$ error in depth and $-3.2 \%$ error in GTG. Therefore, the observed GTG decrease of $13-31 \%$ in slope basin and inner toe-thrust areas and increase of 15-20\% in the vicinity of the fault systems are beyond the errors introduced by inaccurate velocity. In addition, the presence of fracture-filled gas hydrate in KG offshore basin leads to an anisotropic model (Lee and Collett, 2009; Sriram et al., 2014). If the medium is anisotropic, RMS velocity is different from the vertical velocity leading to error in the estimation of depth and GTG. A rough estimate of error in GTG due to anisotropy is of the order of 3-4 \% (Dewangan et al., 2011) which is much smaller than the observed GTG anomaly. Another important factor which can affect the GTG estimation is salinity; High salinity pore-water may shift the phase 
curve of methane + seawater to lower temperatures. In the present study, a constant salinity of $35 \mathrm{~g} / \mathrm{l}$ is assumed for the calculation of phase curve. A considerable increase in salinity of $50 \mathrm{~g} / \mathrm{l}$ is required to explain the observed increase in GTG (Dewangan et al., 2011). Such an increase in salinity is possible immediately after the formation of gas hydrate, but the salinity values will slowly decrease to the background value due to diffusion. Thus, the increase in GTG due to salinity is unlikely and decrease in GTG cannot be explained by the salinity effect. The observed anomaly in GTG is beyond the error introduced due to inaccuracy in velocity or variation in salinity due to hydrate formation.

\section{Conclusions}

Distinct geomorphic features such as mounds/ridges formed due to outer and inner toe trusts, several mass transport deposits in the midslope basin, and system of linear faults have been identified based on the analysis of 3D seismic data in KG offshore basin. The mounds, ridges and slope basin are formed due to the ongoing shale/neo tectonism in KG offshore basin. Further, slumping/sliding of upper slope sediments, associated with fluid/gas migration has led to several MTDs in the midslope basin. The BSR-derived GTG from 3D seismic data shows strong correlation with the topography. An anomalous decrease in GTG by $13-31 \%$ is observed over the mounds formed due to inner toe-thrust and the intra-slope basin filled with MTDs. In contrast, the mounds which are formed due to outer toethrust show an increase in GTG by $15-20 \%$ in the vicinity of fault systems. Various sources of uncertainty like gas composition, salinity, seafloor temperature, velocity, and anisotropy are studied for the computation of GTG. It is found that the observed anomalies are beyond the error introduced by these factors. Furthermore, it is difficult to explain the magnitude and extend of the GTG anomalies by considering 1D effect of seabed topography. Therefore, we propose that the low GTG anomaly over the mound $M_{4}$ is due to the rapid upliftment of the sediment and likewise low GTG over MTDs is due to rapid sedimentation. The increase in GTG has been attributed to fluid advection along the fault system. In order to understand the contribution due to various processes, a detailed thermal modeling involving the effect of surface topography, high sedimentation rates and tectonic upliftment is warranted.

\section{Acknowledgments}

The authors wish to thank those that contributed to the success of the National Gas Hydrate Program Expedition 01 (NGHP-01). NGHP-01 was planned and managed through collaboration between the Directorate General of Hydrocarbons (DGH) under the Ministry of Petroleum and Natural Gas (India), the U.S. Geological Survey (USGS), and the Consortium for Scientific Methane Hydrate Investigations (CSMHI) led by Overseas Drilling Limited (ODL) and FUGRO McClelland Marine Geosciences (FUGRO). The platform for the drilling operation was the research drill ship JOIDES Resolution, operated by ODL. Much of the drilling/coring equipment used was provided by the 
Integrated Ocean Drilling Program (IODP) through a loan agreement with the US National Science Foundation. Wireline pressure coring systems and supporting laboratories were provided by IODP/Texas A\&M University (TAMU), FUGRO, USGS, U.S. Department of Energy (USDOE) and HYACINTH/GeoTek. Downhole logging operational and technical support was provided by LamontDoherty Earth Observatory (LDEO) of Columbia University. The financial support for the NGHP-01, from the Oil Industry Development Board, Oil and Natural Gas Corporation Ltd., GAIL (India) Ltd. and Oil India Ltd. is gratefully acknowledged. We also acknowledge the support extended by all the participating organizations of the NGHP: MoP\&NG, DGH, ONGC, GAIL, OIL, NIO, NIOT, and RIL. The Director of National Institute of Oceanography (NIO) and Director General of Directorate General of Hydrocarbons (DGH) are thanked for encouragement, support and the permission to publish. We would like to thank the reviewers for providing useful comments/suggestions which has improved the quality of the manuscript. We would like to acknowledge the support of ONGC for providing 3D seismic data. Special thanks to A. V. Sathe (ONGC), P. Kumar (ONGC), and M. V. Lall (DGH) for providing useful comments/suggestions which has improved the quality of the manuscript. This is NIO contribution no. $x x x$.

\section{References}

Bastia, R., Nayak, P.K., 2006. Tectonostratigraphy and depositional patterns in Krishna offshore basin, Bay of Bengal. The Leading Edge 25, 839-845.

Bastia, R., 2006. An overview of Indian sedimentary basins with special focus on emerging east coast deepwater frontiers. The Leading Edge 25, 818-829.

Basu, S., 1990.Clay mineralogy and pressure analysis from seismic information in Krishna-Godavari basin, India. Geophysics 55, 1447-1454.

Brooks, J.M., Cox, B., Bryant, W.R., Kennicutt II, M.C., Mann, R.G., McDonald, T.J., 1986. Association of gas hydrates and oil seepage in the Gulf of Maxico. Advances in Organic Geochemistry 10, 221-234.

Bugge, T., Befring, S., Belderson, R.H., Eidvin, T., Jansen, E., Kenyon, N.H., Holtedahl, H., Serjup, H.P., 1987.A giant three-stage submarine slide off Norway. Geo-Marine Letters 7, 191-198.

Collett, T.S., et al., 2008. Results of the Indian National Gas Hydrate Program Expedition 01 Initial Reports, Report. Director General of Hydrocarbons, Ministry of Petroleum and Natural Gas, New Delhi.

Cooper, A.K., Hart, P.E., 2002. High-resolution seismic-reflection investigation of northern Gulf of Maxico.Marine and Petroleum Geology 19, 1275-1293.

Damuth, J.E., 1994. Neogene gravity tectonics and depositional processes on the deep Niger Delta continental margin. Marine and Petroleum Geology 11, 320-346. 
Davis, E.E., Hyndman, R.D., Villinger, H., 1990. Rates of fluid expulsion across the northern Cascadia accretionary prism: Constraints from new heat flow and multichannel seismic reflection data. Journal of Geophysical Research 95, 8869-8889.

De Batist, M., Klerkx, J., Van Rensbergen, P., Vanneste, M., Poort, J., Golmshtok, A.Y., Kremlev, A.A., Khlystov, O.M., Krinitsky, P., 2002. Active hydrate destabilization in Lake Baikal, Siberia?. Terra Nova 14, 436-442.

Dewangan, P., Ramprasad, T., Ramana, M.V., Mazumdar, A., Desa, M., Badesab, F.K., 2010. Seabed morphology and gas venting features in the continental slope region of Krishna-Godavari basin, Bay of Bengal: Implications in gas-hydrate exploration. Marine and Petroleum Geology 27, 1628-1641.

Dewangan, P., Sriram, G., Ramprasad, T., Ramana, M.V., Jaiswal, P., 2011. Fault system and thermal regime in the vicinity of site NGHP-01-10, Krishna-Godavari basin, Bay of Bengal. Marine and Petroleum Geology 28, 1899-1914.

Ganguly, N., Spence, G.D., Chapman, N.R., Hyndman, R.D., 2000. Heat flow variations from bottom simulating reflectors on the Cascadia margin. Marine Geology 164, 53-68.

Gupta, S.K., 2006. Basin architecture and petroleum system of Krishna Godavari Basin, East coast of India. The Leading Edge 25, 830-837.

Helgerud, M.B., Dvorkin, J., Nur, A., Sakai, A., Collett, T., 1999. Elastic-wave velocity in marine sediments with gas hydrates: Effective medium modeling. Geophysical Research Letters 26, 2021-2024.

Holbrook, W.S., Hoskins, H., Wood, W.T., Stephen, R.A., Lizarralde, D., 1996. Methane hydrate and free gas on the Blake ridge from vertical seismic profiling. Science 273, 1840-1843.

Hovland, M., Judd, A. G. 1988 Seabed pockmarks and seepages: impact on biology, geology and the environment. London: Graham \&Trotman.

Hyndman, R.D., Spence, G.D., 1992. A seismic study of methane hydrate marine bottom simulating reflectors. Journal of Geophysical Research 97, 6683-6698.

Hyndman, R. D., Wang, K., Yuan, T., Spence, G. D., 1993. Tectonic sediment thickening, fluid expulsion, and the thermal regime of subductionzone accretionary prisms: The Cascadia margin off Vancouver Island. Journal of Geophysical Research 98.21865-21876.

Judd, A.G., 2003. The global importance and context of methane escape from the seabed. Geo-Marine Letters 23, 147-154.

Johnson, B.D., Powell, C.M., Veevers, J.J., 1980. Early spreading history of the Indian ocean between India and Australia. Earth and Planetary Science Letters, 47, 131-143.

Kaul, N., Rosenberger, A., Villinger, H., 2000. Comparison of measured and BSR-derived heat flow values, Makran accretionary prism, Pakistan. Marine Geology164, 37-51.

Kvenvolden, K.A., 1993. Gas hydrates-geological perspective and global change. Reviews of Geophysics 31, 173-187. 
Kvenvolden, K.A., Ginsburg, G.D., Soloviev, V.A., 1993. Worldwide distribution of subaquatic gas hydrates. Geo-Marine Letters 13, 32-40.

Lachenbruch, A.H., 1968. Rapid estimation of the topographic disturbance to superficial thermal gradients. Reviews of Geophysics 6, 365-400.

Lee, M. W., Collett, T. S., 2009. Gas hydrate saturations estimated from fractured reservoir at site NGHP-01-10, Krishna-Godavari basin, India. Journal of Geophysical Research: Solid Earth 114(B7), 1978-2012.

Liner, D., 1990. General theory and comparative anatomy of dip moveout. Geophysics 55, 595-607.

Mann, D., Kukowski, N., 1999. Numerical modelling of focussed fluid flow in theCascadia accretionary wedge. Journal of Geodynamics 27, 359-372.

Mazumdar,A., Dewangan, P., Joäo, H.M., Peketi, A., Khosla, V.R., Kocherla, M., Badesab, F.K., Joshi, R.K., Roxanne, P., Ramamurty, P.B., Karisiddaiah, S.M., Patil, D.J., Dayal, A.M., Ramprasad, T., Hawkesworth, C.J., Avanzinelli, R., 2009. Evidence of paleo-cold seep activity from the Bay of Bengal, offshore India. Geochemistry, Geophysics, Geosystems 10 (6), 1-15.

Mazumdar, A., João, H.M., Peketi, A., Dewangan, P., Kocherla, M., Joshi, R.K., Ramprasad, T., 2012. Geochemical and geological constraints on the composition of marine sediment pore fluid: possible link to gas hydrate deposits. Marine and Petroleum Geology 38, 35-52.

Miles, P.R., 1995. Potential distribution of methane hydrate beneath the European continental margins. Geophysical Research Letters 22, 3179-3182.

Minshull, T., White, R., 1989.Sediment compaction and fluid migration in the Makran Accretionary prism.Journal of Geophysical Research 94, 7387-7402.

Nimblett, J.N., Shipp, R.C., Strijbos, F., 2005. Gas hydrate as a drilling hazard: examples from global deepwater settings. In Offshore Technology Conference, Houston, Texas, OTC Paper 17476, 17.

NIO, 1997. Gas Hydrate resource map of India. Rep no.NIO/SP-25/97. National Institute of Oceanography, Dona-Paula, Goa.

Prabhakar, K.N., Zutshi, P.L., 1993. Evolution of southern part of Indian east coast basins. Journal of the Geological Society of India 41, 215-230.

Pecher, I.A., Henrys, S.A., Wood, W.T., Kukowski, N., Crutchley, G.J., Fohrmann, M., Kilner, J., Senger, K., Gorman, A.R., Coffin, R.B., Greinert, J., Faure, K., 2009.Focussed fluid flow on the Hikurangi Margin, New Zealand -evidence from possible local upwarping of the base of gas hydrate stability. Marine Geology 272, 99-113.

Powell, C.M., Roots, S.R., Veevers, J.J., 1988. Pre-breakup continental extension in East Gondwanaland and the early opening of the eastern Indian Ocean. Tectonophysics 155, $261-$ 283.

Ramana, M.V, Nair, R.R., Sarma, K.V.L.N.S., Ramprasad, T., Krishna, K.S., Subrahmanyam V., D'Cruz, M., Subrahmanyam, C., Paul, J., Subrahmanyam, A.S., Sekhar, D.V.C., 1994.Mesozoic 
anomalies in the Bay of Bengal. Earth and Planetary Science Letters 121, 469-475.

Ramana, M.V., Ramprasad, T., Desa, M., Sathe, A.V., Sethi, A.K., 2006. Gas hydrate-related proxies inferred from multidisciplinary investigations in the Indian offshore areas. Current Science 91, 183-189.

Ramana, M.V., Ramprasad, T., Paropkari, A.L., Borole, D.V., Ramalingeswara Rao, B., Karisiddaiah, S.M., Desa, M., Kocherla, M., Joao, H.M., Lokabharati, P., Gonsalves, MariaJudith, Pattan, J.N., Khadge, N.H., Prakash Babu, C., Sathe, A.V., Kumar, P., Sethi, A.K., 2008. Multidisciplinary investigations exploring indicators of gas hydrate occurrence in the KrishnaGodavari Basin offshore, east coast of India. Geo-Marine Letters 29(1), 25-38.

Ramprasad, T., Dewangan, P., Ramana, M.V., Mazumdar, A., Karisiddaiah, S.M., Ramya, E.R., Sriram, G., 2011.Evidence of slumping/sliding in Krishna-Godavari offshore basin due to gas/fluid movements. Marine and Petroleum Geology 28, 1806-1816.

Rao, G.N., Mani, K.S., 1993. A study on generation of abnormal pressures in Krishna-Godavari basin. Indian Journal of Petroleum Geology 2, 20-30.

Rao, G.N., 1993. Geology and hydrocarbon prospects of east coast sedimentary basin of India with special reference to Krishna-Godavari basin. Journal of the Geological Society of India 41, 444454.

Rao, G.N., 2001. Sedimentation, stratigraphy, and petroleum potential of Krishna-Godavari basin, East Coast of India. AAPG Bulletin 85, 1623-1643.

Riedel, M., Novosel, I., Spence, G.D., Hyndman, R.D., Chapman, R.N., Solem, R.C., Lewis, T., 2006. Geophysical and Geochemical signatures associated with gas hydrate-related venting in the northern Cascadia margin. Geological Society of American Bulletin 118, 23-38.

Riedel, M., Collett, T.S., Kumar, P., Sathe, A.V., Cook, A., 2010. Seismic imaging of a fractured gas hydratesystem in the Krishna-Godavari basin offshore India. Marine and Petroleum Geology 27, 1476-1493.

Riedel, M., Collett, T.S., Shankar, U., 2011. Documenting channel features associated with gas hydrates in the Krishna-Godavari basin, offshore India. Marine Geology 279, 1-11.

Ruppel, C.Y., Kinoshita, M., 2000. Fluid, methane, and energy flux in an active margin gas hydrate province, offshore Costa Rica. Earth and Planetary Science Letters 179, 153-165.

Ruppel, C., Dickens, G.R., Castelline, D.G., Gilhooly, W., Lizarralde, D., 2005. Heat and salt inhibition of gas hydrate formation in northern Gulf of Maxico. Geophysical Research Letters 32, 1-4.

Sain, K., Rajesh, V., Satyavani, N., Subbarao, K. V., Subrahmanyam, C., 2011. Gas-hydrate stability thickness map along the Indian continental margin. Marine and Petroleum Geology 28, 17791786.

Shankar, U., Riedel, M., 2010. Seismic and heat flow constraints from the gas hydrate system in the Krishna-Godavari Basin, India. Marine Geology 276, 1-13.

Shankar, U., Riedel, M., 2013. Heat flow and gas hydrate saturation estimates from Andaman Sea, 
India. Marine and Petroleum Geology 43, 434-449.

Shi, Y., Wang, C., Langseth, M.G., Hobart, M., von Huene, R., 1988. Heat flow and thermal structure of the Washington-Oregon accretionary prism-A study of the lower slope. Geophysical Research Letters 15, 1113-1116.

Shipley, T.H., Houston, M.H., Buffler, R.T., Shaub, F.J., McMillen, K.J., Ladd, J.W., Worzel, J.L., 1979. Seismic evidence for widespread possible gas hydratehorizons on continental slopes and rises. AAPG Bulletin 63, 2204-2213.

Sloan, E.D., 1990. Clathrate Hydrates of Natural Gases. Marcel Dekker, Inc., NewYork. 641 p.

Sriram, G., Dewangan, P., Ramprasad, T., Rao, R.P., 2013. Anisotropic amplitude variation of the bottom-simulating reflector beneath fracture-filled gas hydrate deposit. Journal of Geophysical Research: Solid Earth, 118(5), 2258--2274.

Stein, C., Stein, S., 1994. Constraints on hydrothermal heat flux through the oceanic lithosphere from global heat flow. Journal of Geophysical Research 99, 3081-3095.

Stolt, R.H., 1978. Migration by Fourier transform. Geophysics 43, 23-48.

Subrahmanyam, C., Chand, S., 2006.Evolution of the passive continental margins of IndiaAGeophysical appraisal.Gondwana Research 10, 167-178.

Wang, K., Hyndman, R.D., Davis, E.E., 1993. Thermal effect of sediment thickening and fluid expulsion in accretionary prisms: Model and parameter analysis. Journal of Geophysical Research 98, 9975-9984.

Wessel, P., Smith,W.H.F., 2013.The Generic Mapping Tools (GMT) version 4.5.9 Technical Reference and Cookbook, SOEST/NOAA.

Zwart, G., Moore, J.C., Cochrane, G.R., 1996. Variations in temperature gradients identify active faults in the Oregon accretionary prism. Earth and planetary science letters 139, 485-495. 


\section{Figure captions}

Figure 1. The location map of the study area in KG offshore basin. The zoom out of the study area with multibeam bathymetry is shown as color image. The boundary of the seismic 3D PSTM data, covering the NGHP sites drilled onboard JOIDES Resolution is marked by a dashed rectangle. The drilling/coring sites during NGHP-01-Expedition (J2/J3/J4/J5/J6/J10/J11/J14) are shown as stars. Major geological features such as mid slope basin, mounds $\left(M_{1}, M_{2}, M_{3}, M_{4}\right)$, delta front, sedimentary ridge $\left(\mathrm{SR}_{1}, \mathrm{SR}_{2}\right)$, outer toe-thrust and channel location are shown on the bathymetry map.

Figure 2.A) Analysis of seafloor time structure (ms); B) Seafloor attribute DIP map. In the DIP map different geomorphologic structures on seafloor are observed.

Figure 3. A) Analysis of seafloor attribute, Azimuth map; B) combined interpretation of seafloor attributes is shown in the background of seafloor azimuth attributes. Curvilinear fault (CF) due to inner toe-thrust, mounds $\left(M_{1}, M_{2}, M_{3}\right)$, MTDs 1-5, and fault systems (F, F1-6) are interpreted in $K G$ offshore basin.

Figure 4. A) GTG variation and seismic profile of line AA'. Seafloor, BSR, Site NGHP-01-14 (J14) is marked on seismic profile; B) GTG variation and seismic profile of line BB'. Seafloor, BSR, Site NGHP01-05 (J5), curved fault system due to inner toe thrust (CF), mounds ( $M_{3}$ and $M_{4}$ ) is marked on the seismic profile; C,D,E) GTG variations and seismic profiles of line CC', DD' and EE'. Seafloor, BSR, curved fault system due to inner toe thrust (CF), mounds ( $\mathrm{M}_{3}$ and $\mathrm{M}_{4}$ ) and fault system (F) are marked on the seismic profiles; F) GTG variation and seismic profile of line FF'. Seafloor, BSR and Site NGHP01-03 are marked on the seismic profile; G,H,I,J,K) GTG variations and seismic profiles of line GG', $\mathrm{HH}^{\prime}, \mathrm{II}^{\prime}, \mathrm{JJ}$ ' and KK'. Seafloor, BSR, mid slope basin, MTDs, faults and mounds are marked on the seismic profiles;

L) GTG variation and seismic profile of line LL'. Seafloor, BSR is marked on seismic profile.

Figure 5. Spatial map of picked BSR time structure using the 3D seismic data in KG offshore basin.

Figure 6. A) GTG variations in the study area. GTG values of Site NGHP-01-03/05/10/14 are plotted on their respective locations; B) Interpretation of GTG map to illustrate the effect of different processes on the estimated GTG.

Figure 7. The RMS velocities obtained from conventional velocity analysis in the study area. The trend of RMS velocities as a function of depth (below seafloor) is shown by solid gray line. 


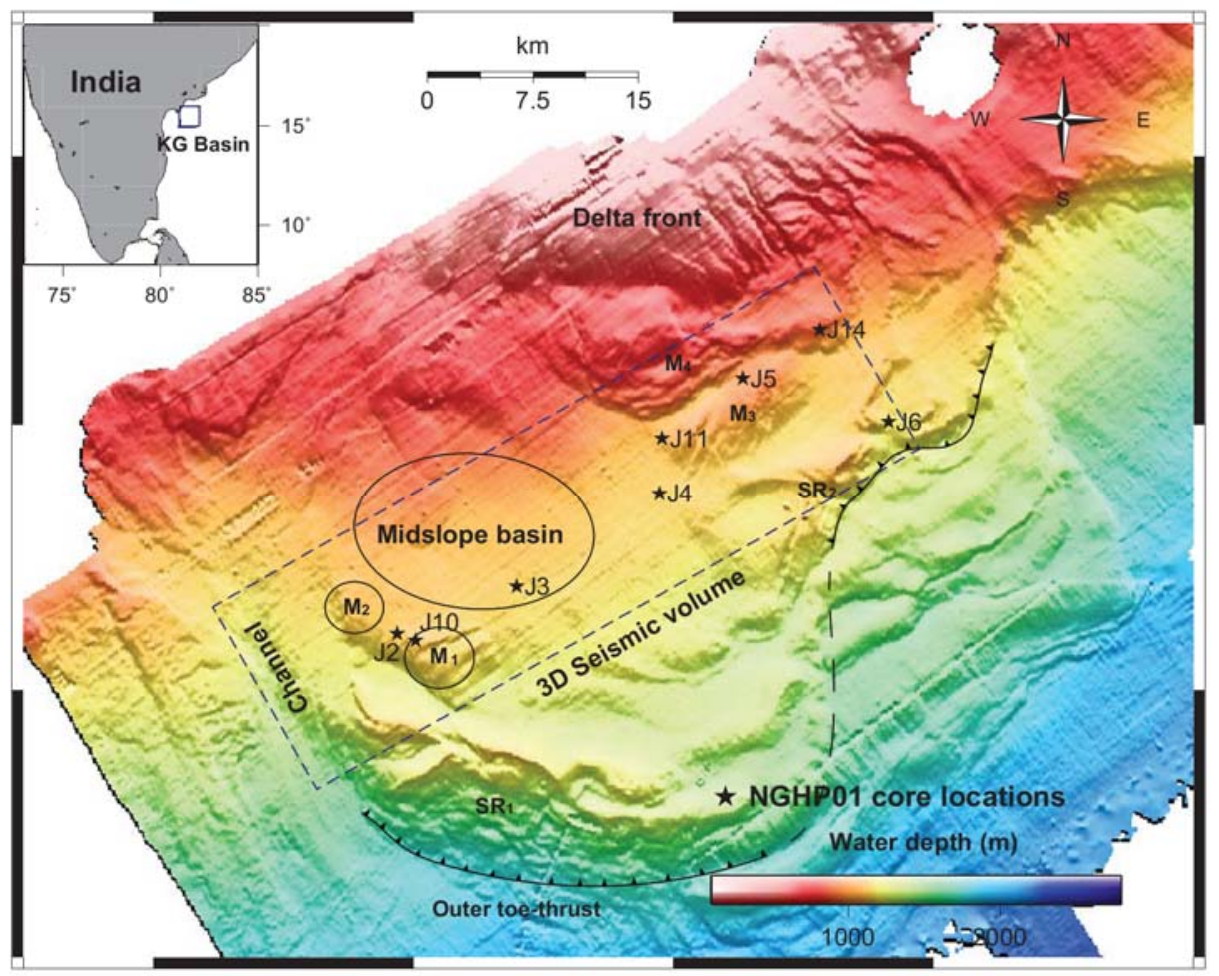

Fig-1
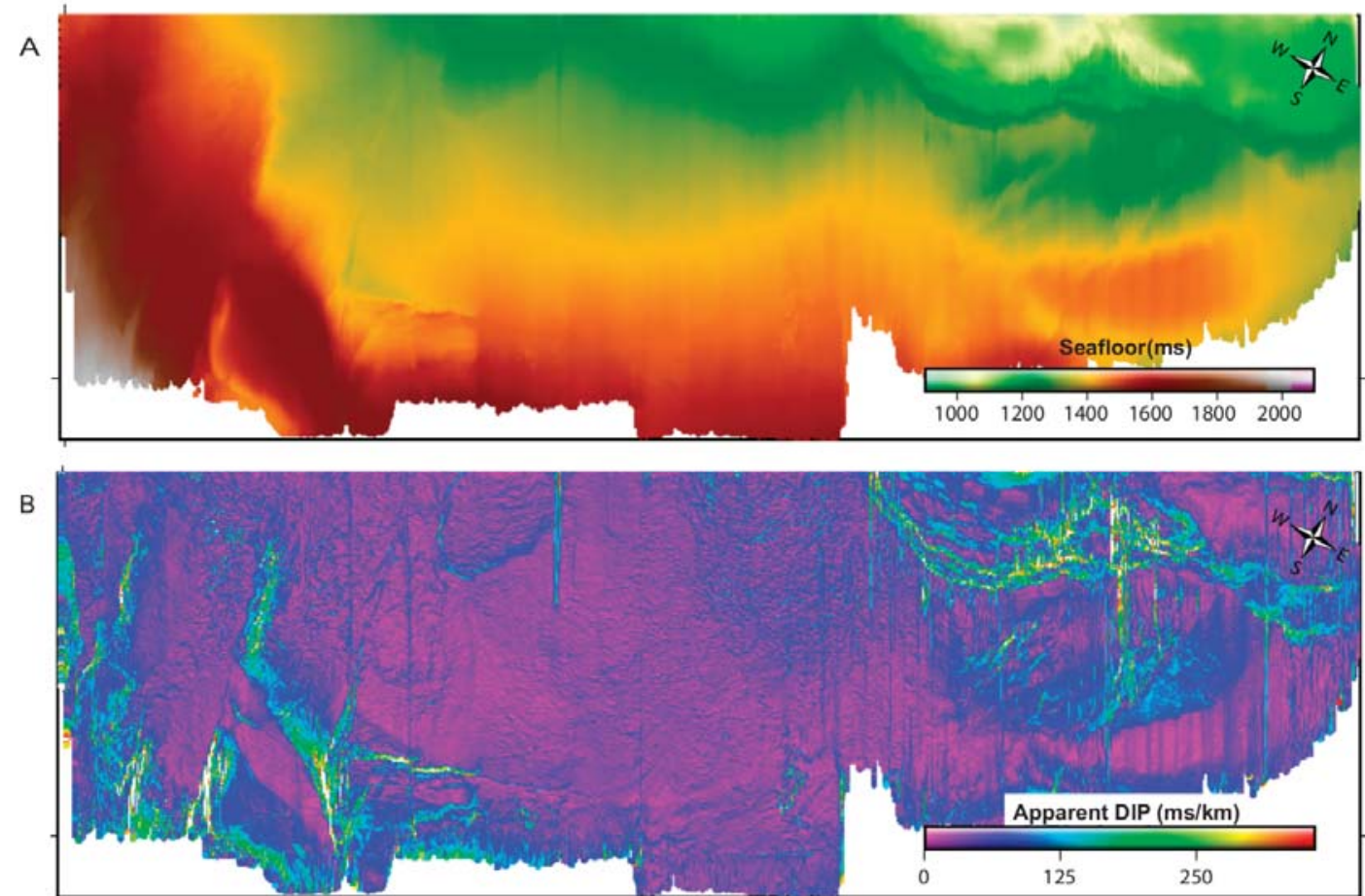

Fig-2 

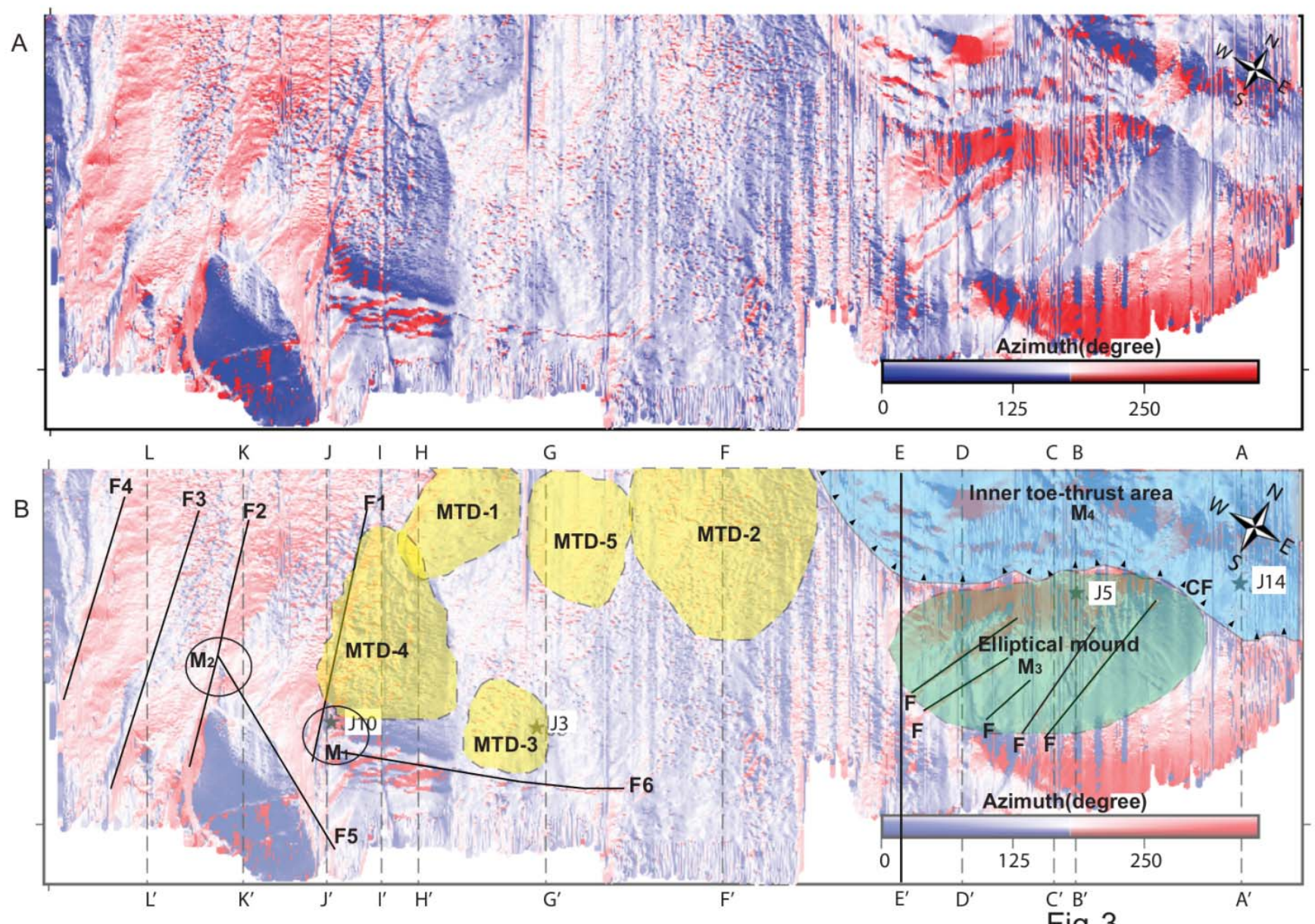

Fig-3 

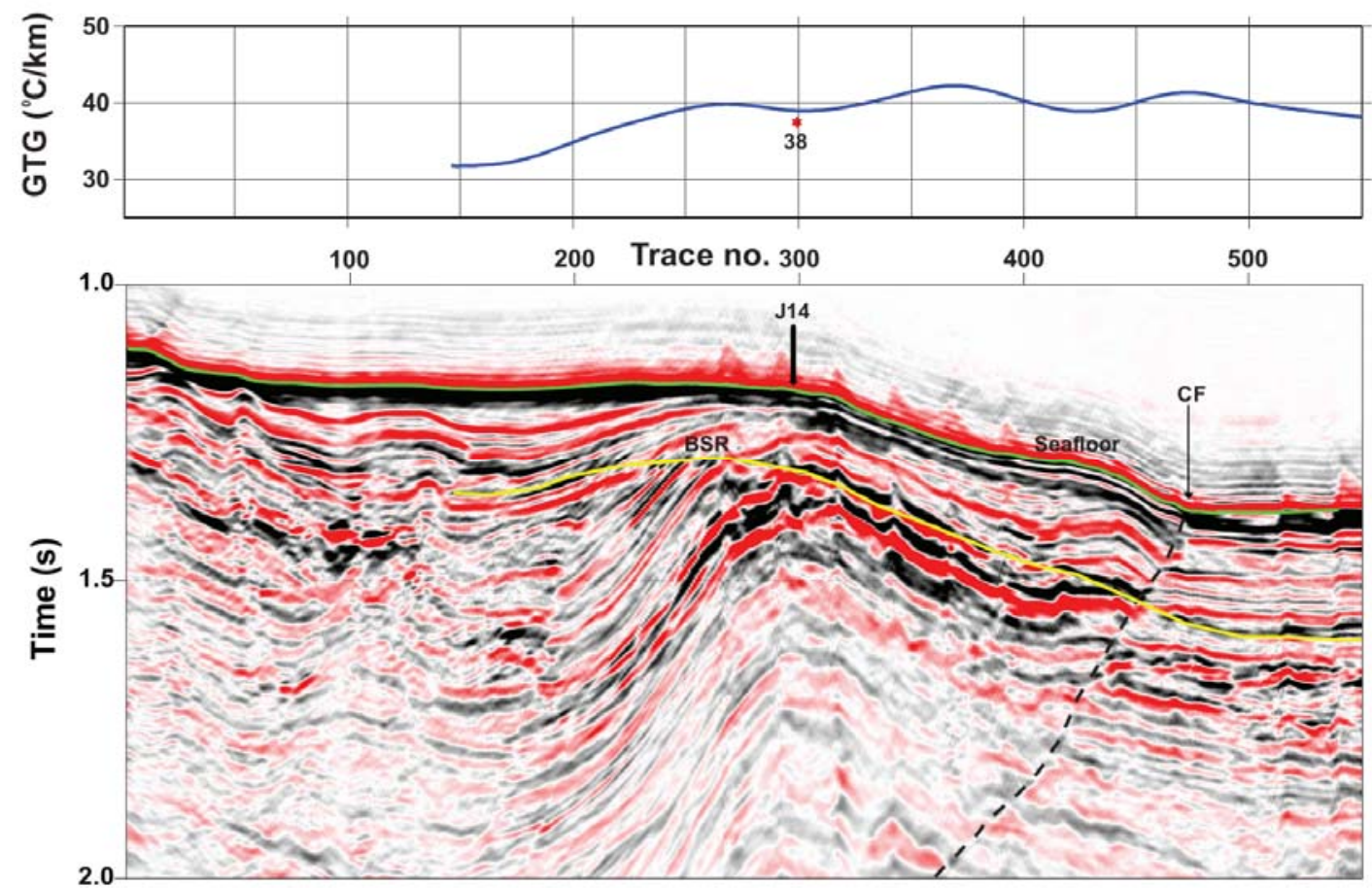

Line no. $A A^{\prime}$

Fig-4A
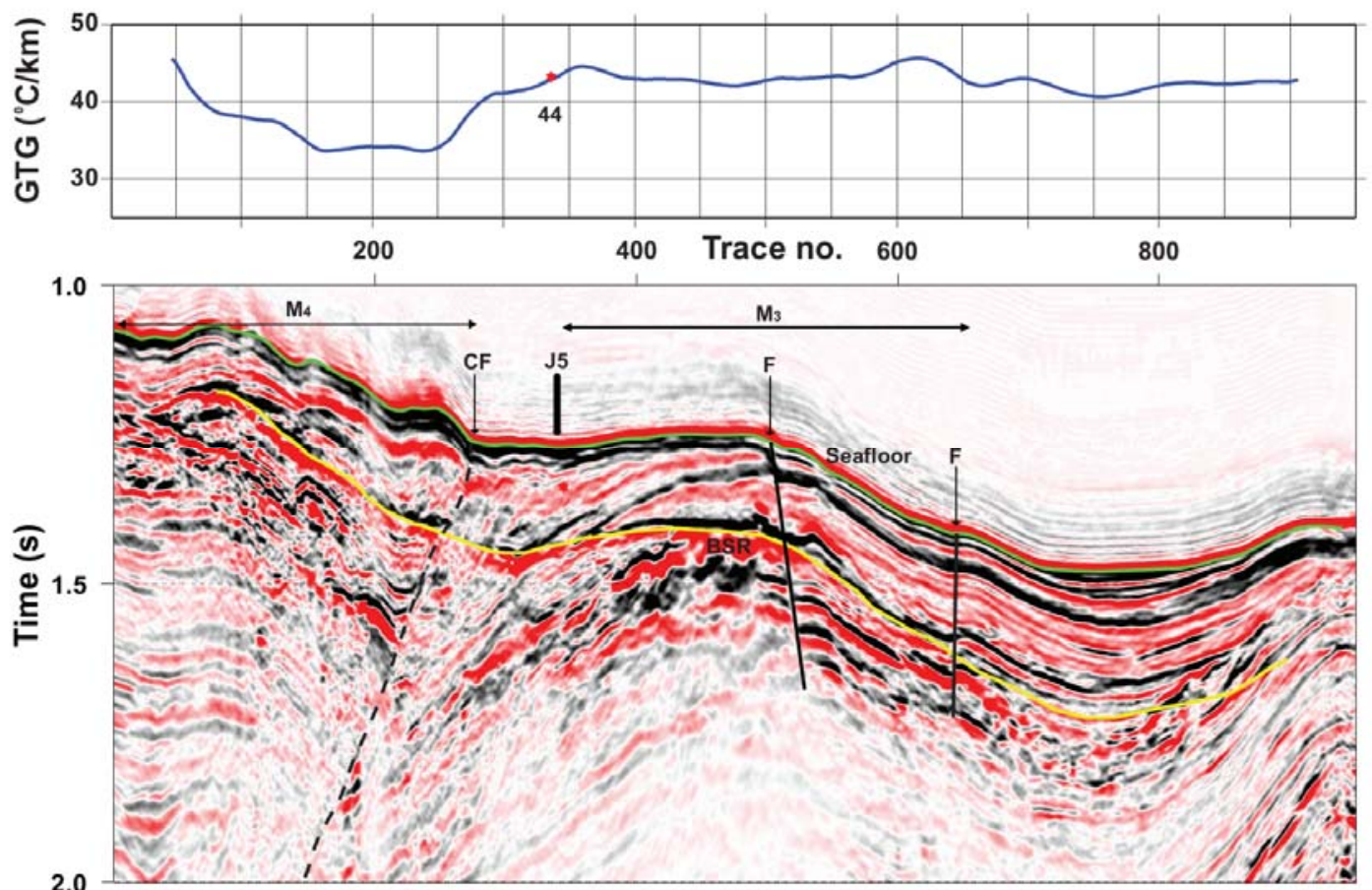

Line no. BB' Fig-4B 

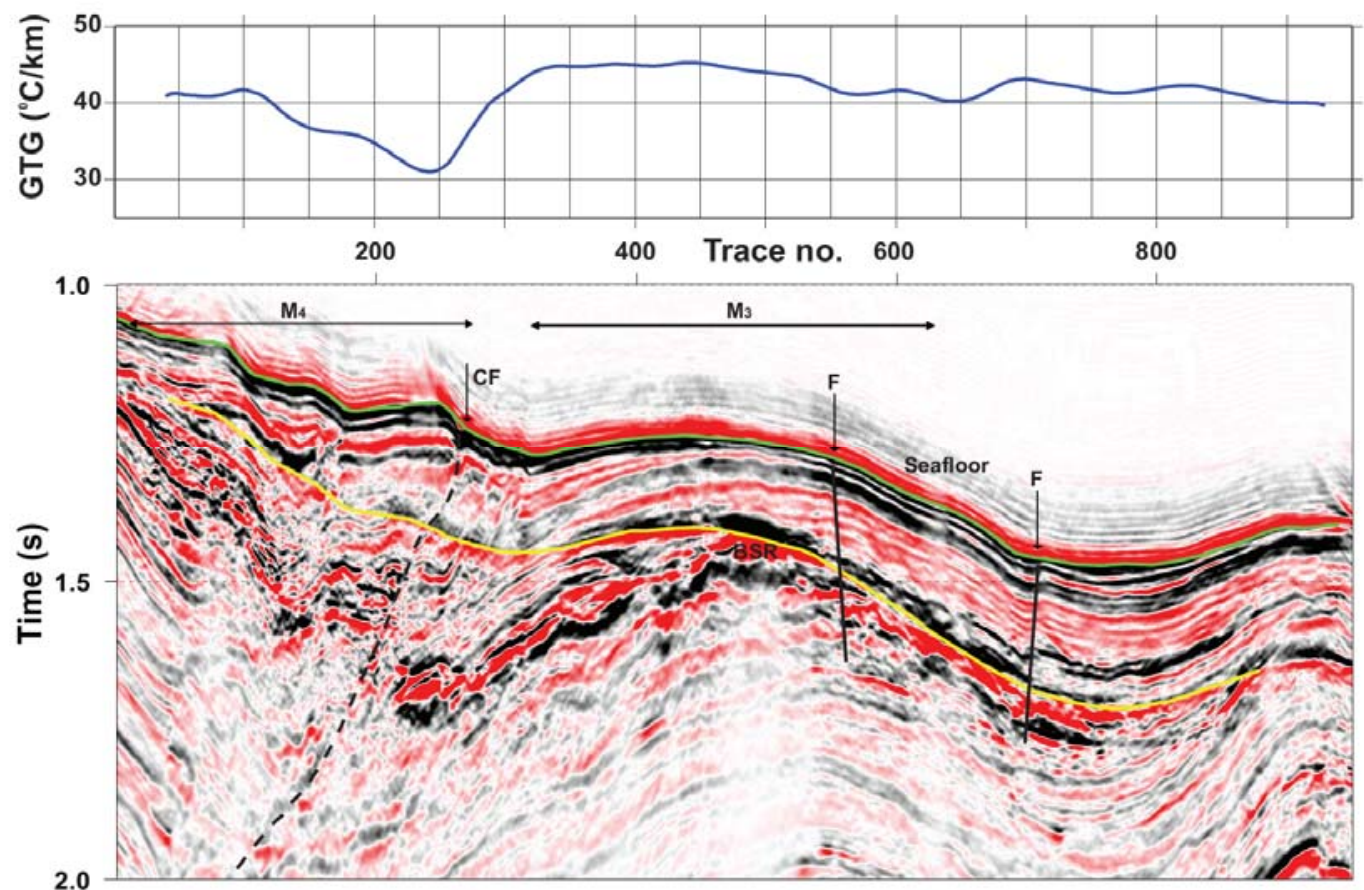

Line no. CC'

Fig-4C
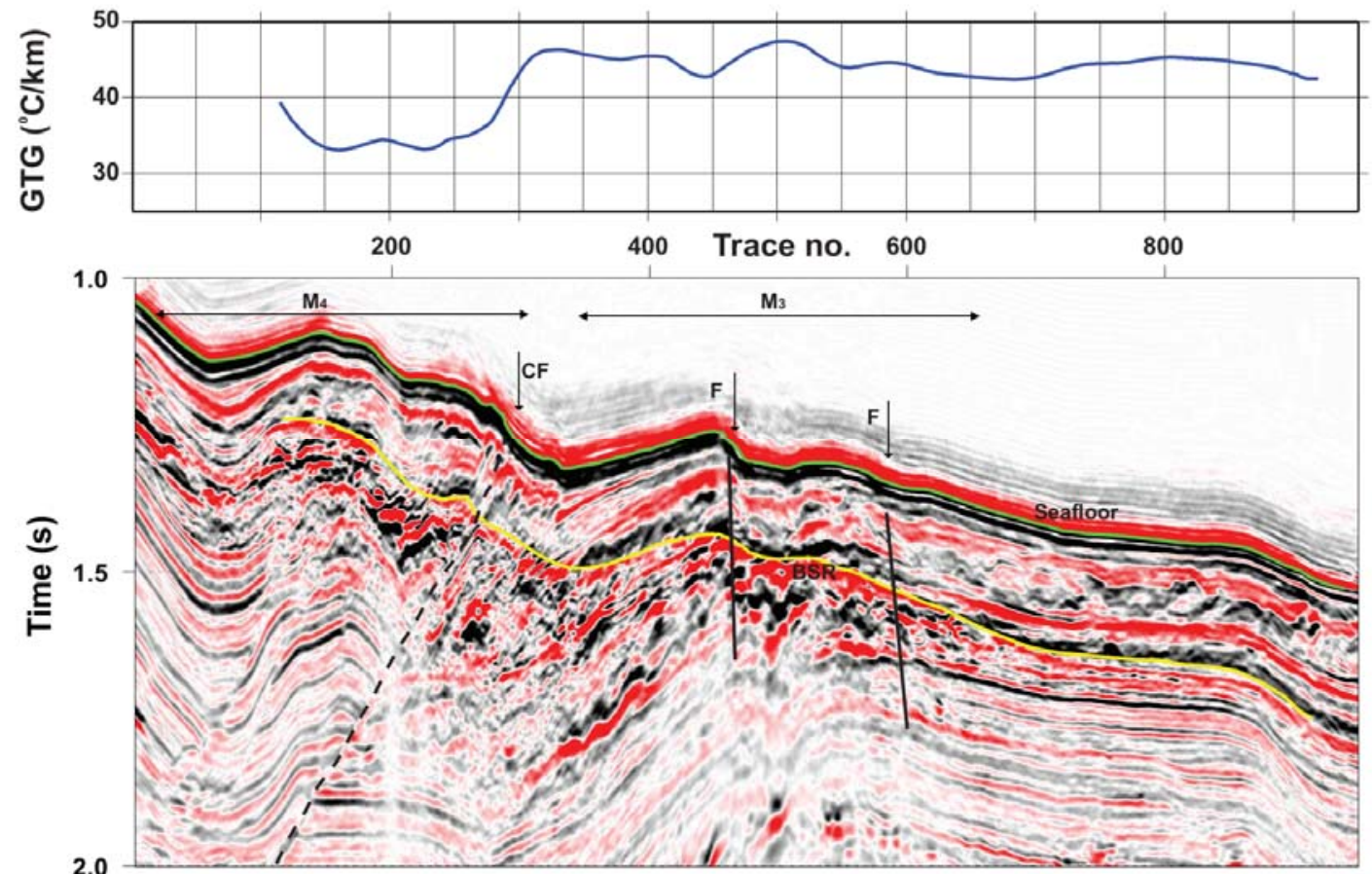

Line no.DD'

Fig-4D 

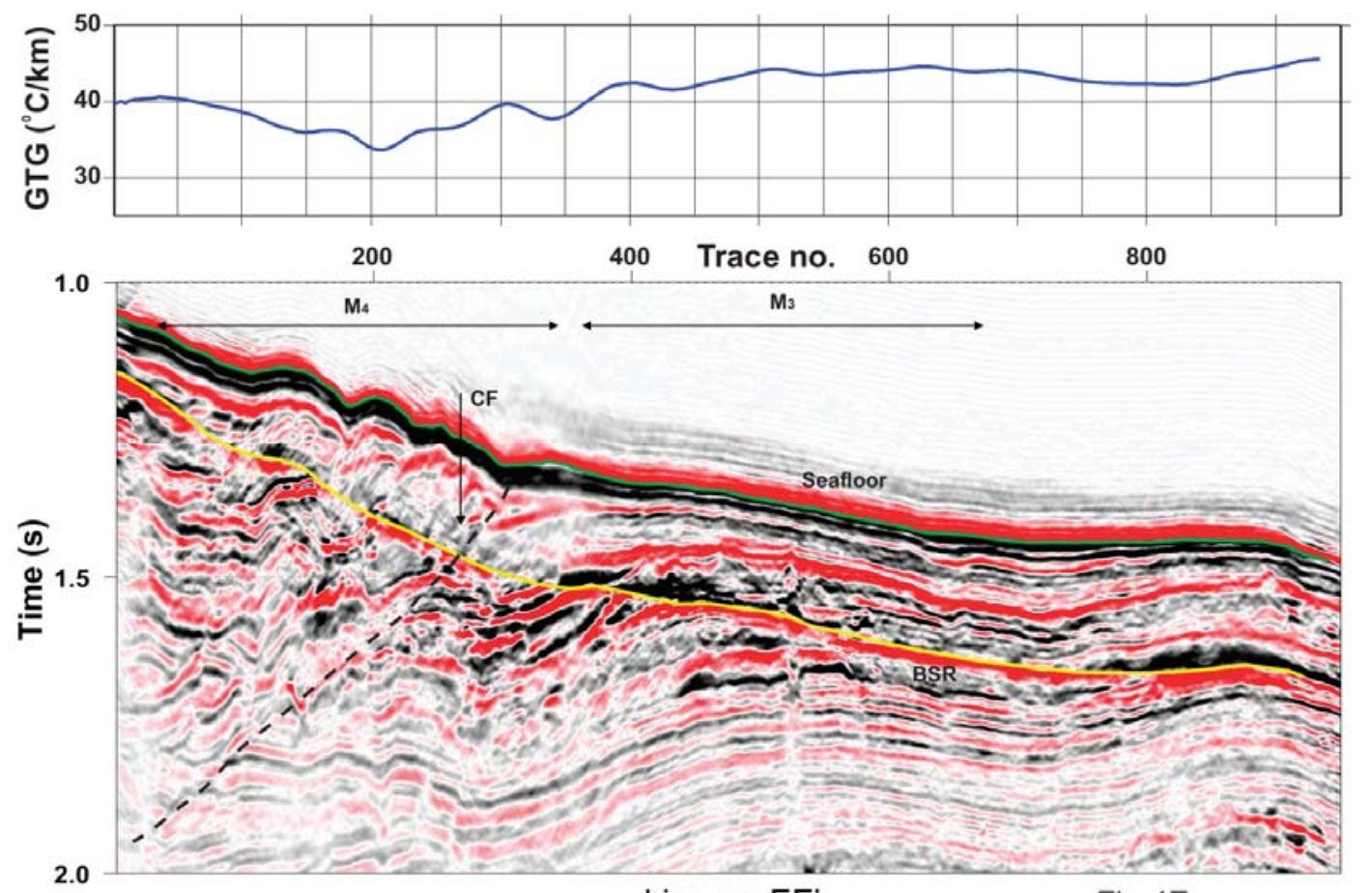

Line no. EE'

Fig-4E
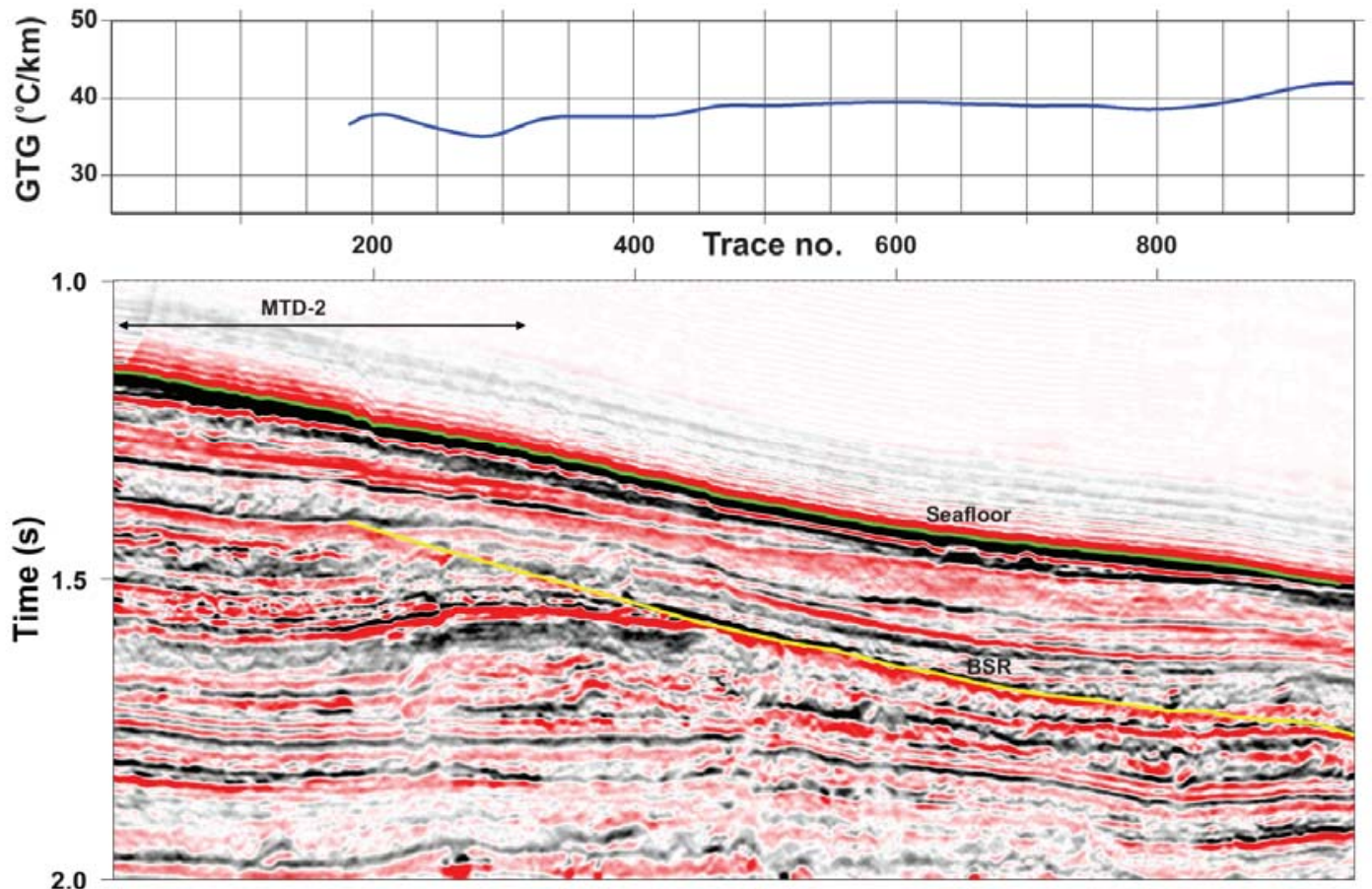

Line no. FF

Fig-4F 

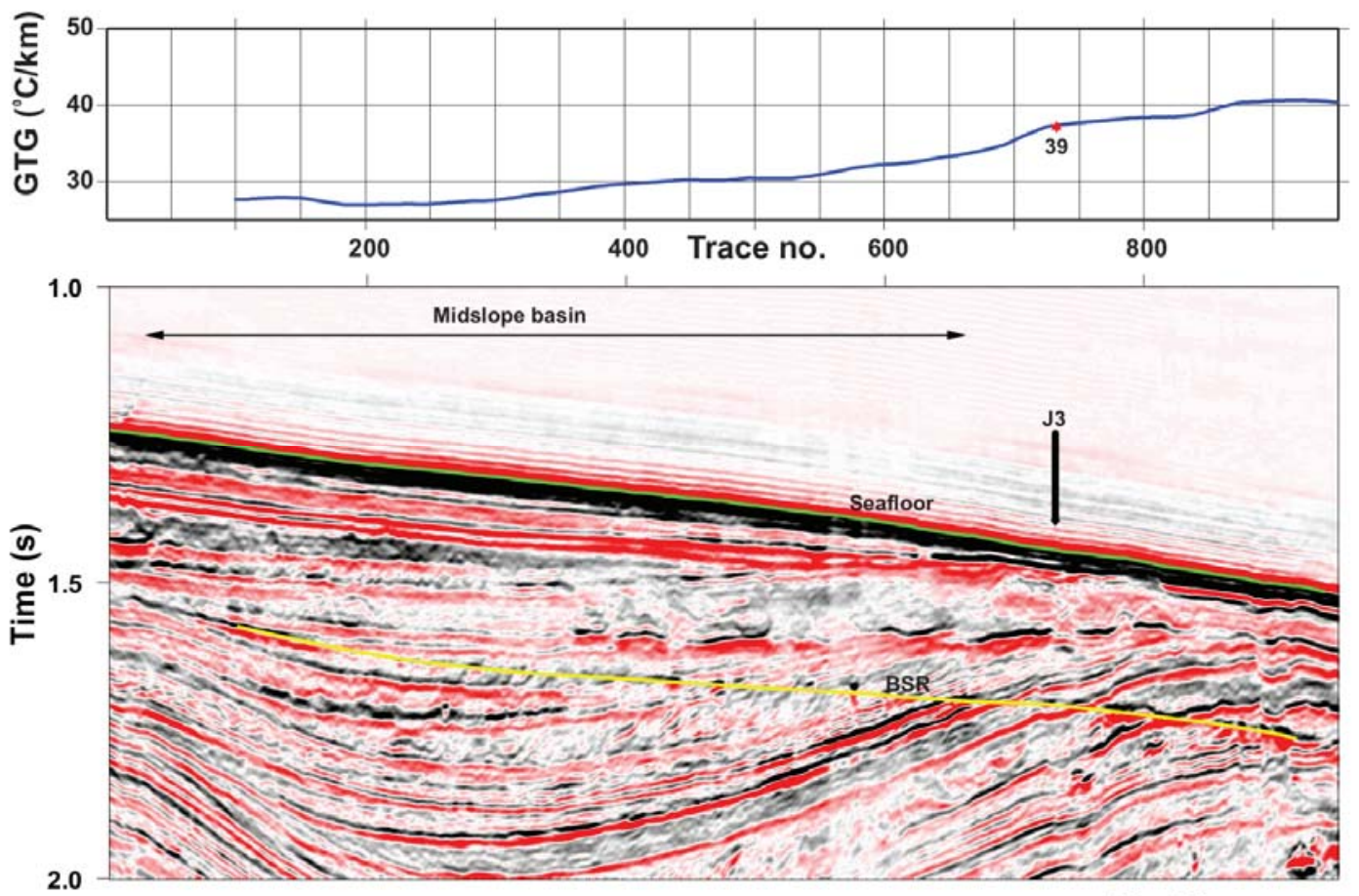

Line no. GG'

Fig-4G
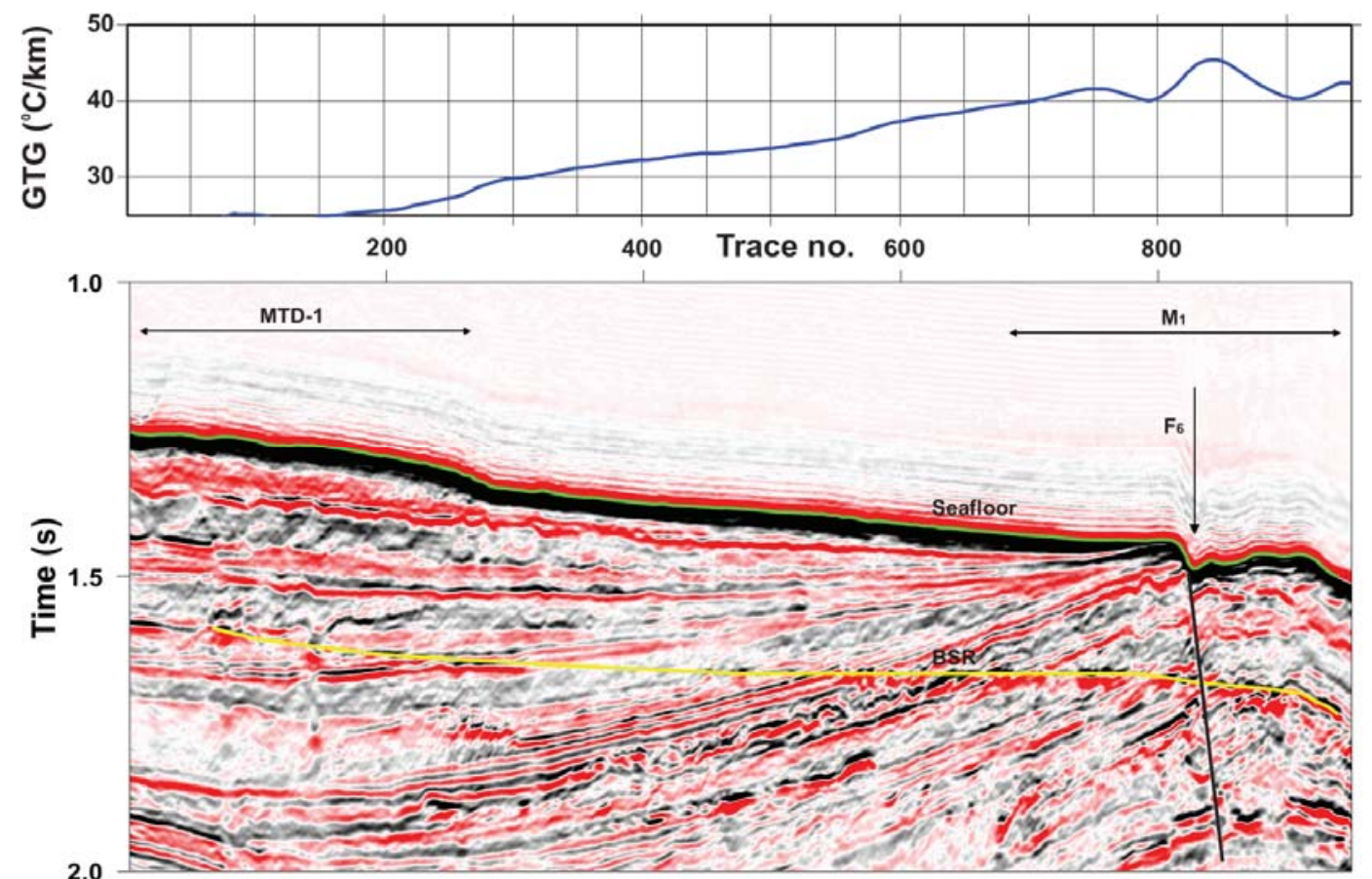

Line no. $\mathrm{HH}^{\prime}$

Fig-4H 

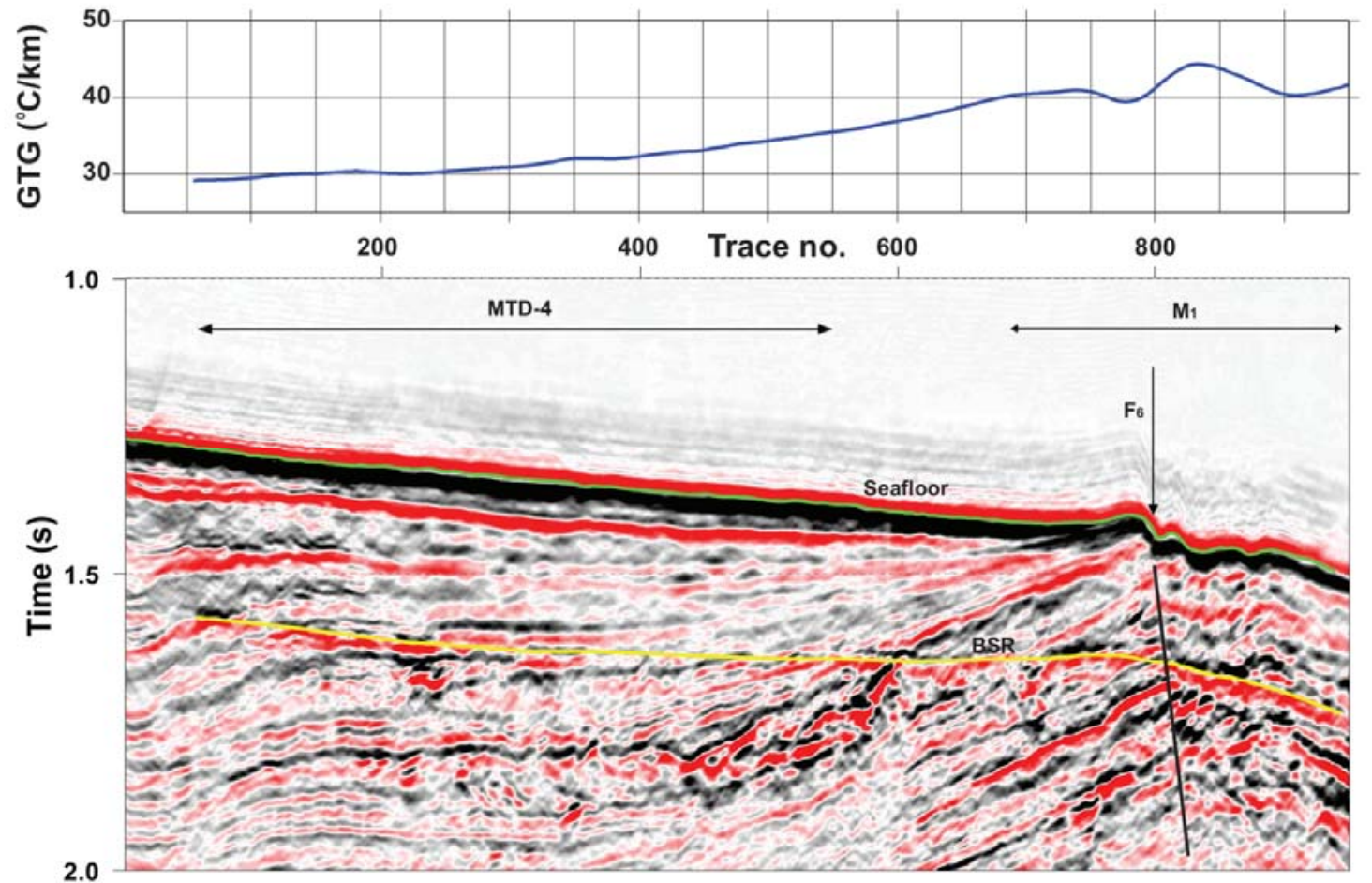

Line no. II'

Fig-4I
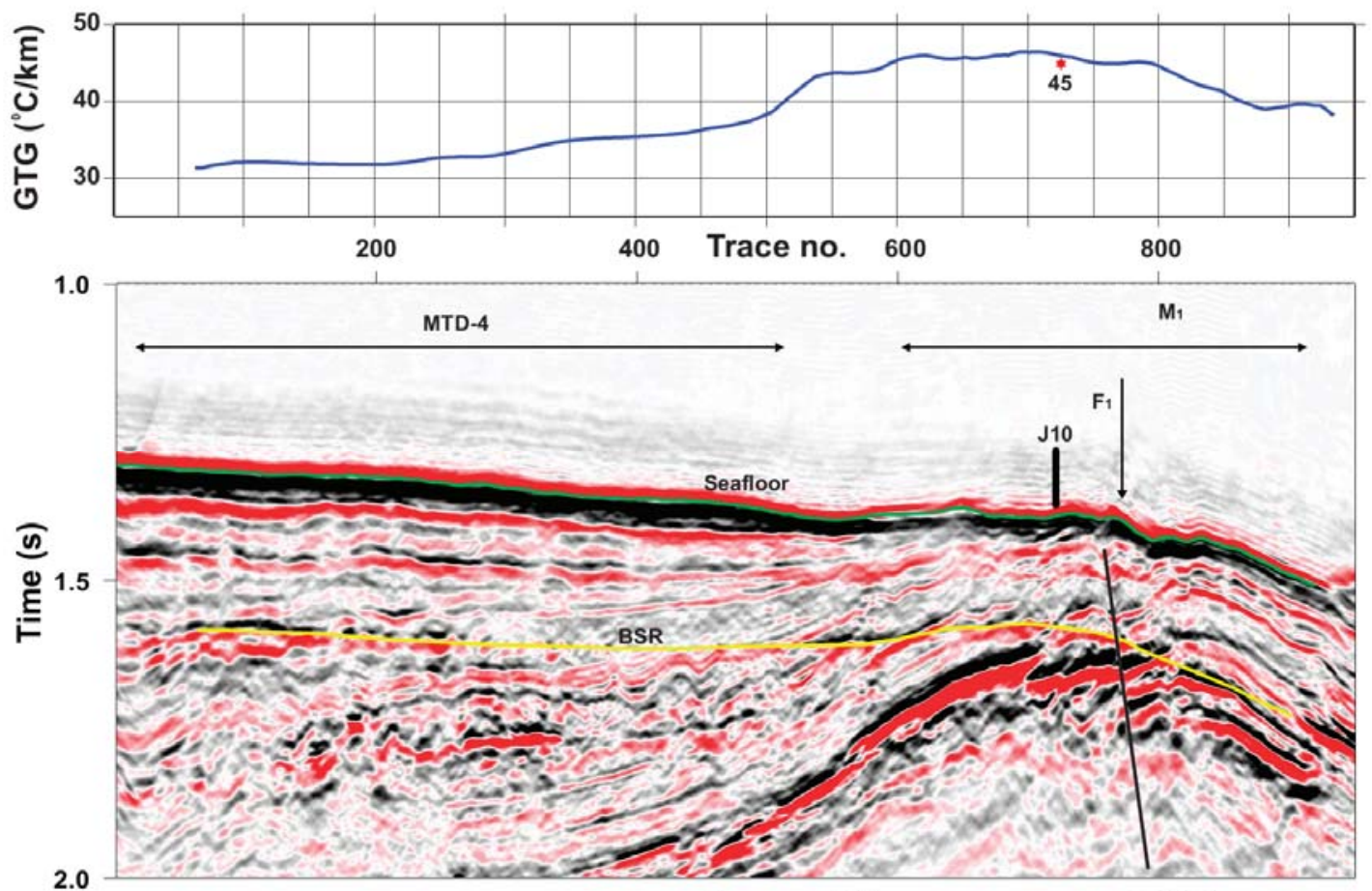

Line no. JJ'

Fig-4J 

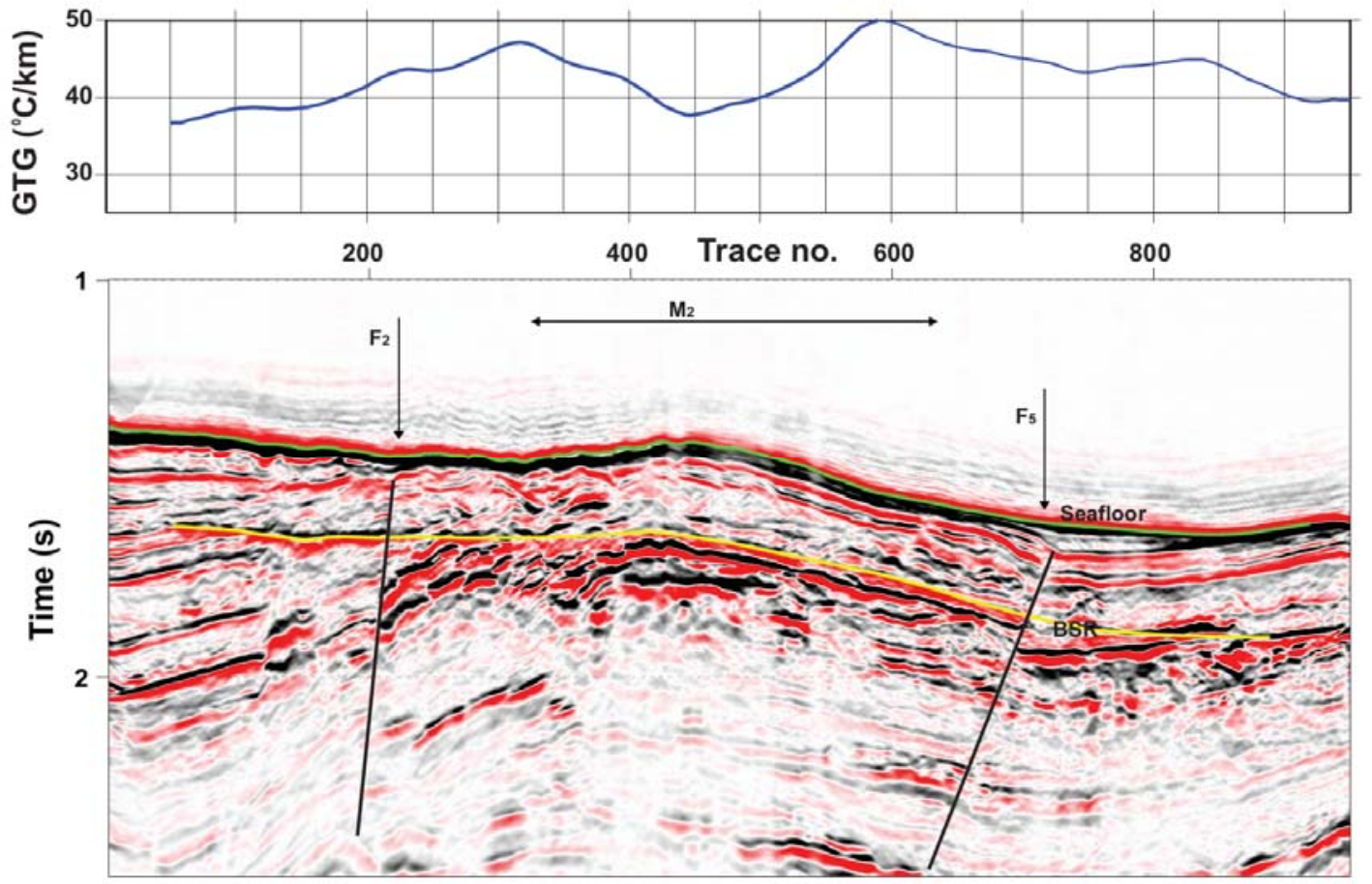

Line no. KK'

Fig-4K
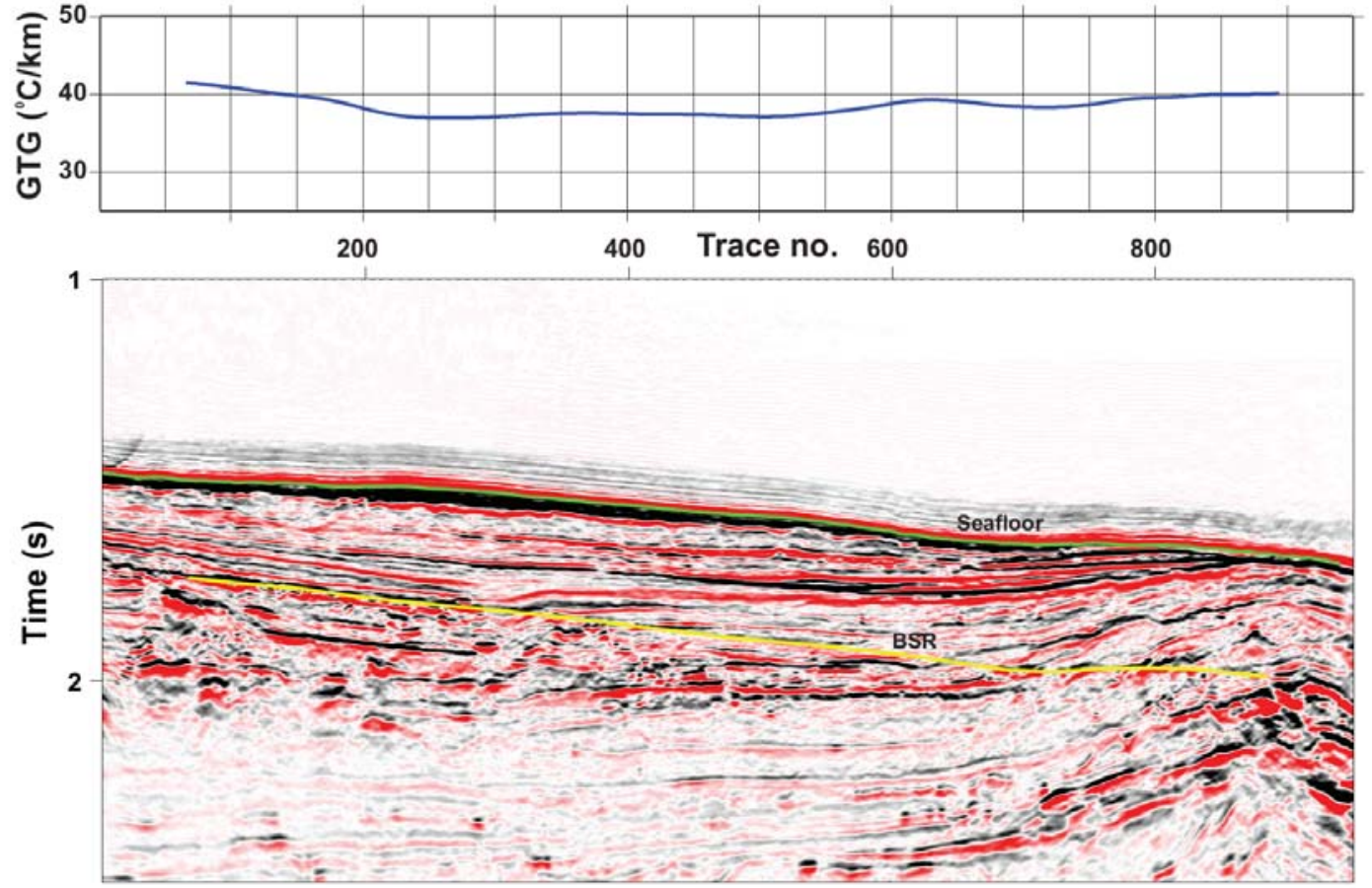

Line no. LL'

Fig-4L 


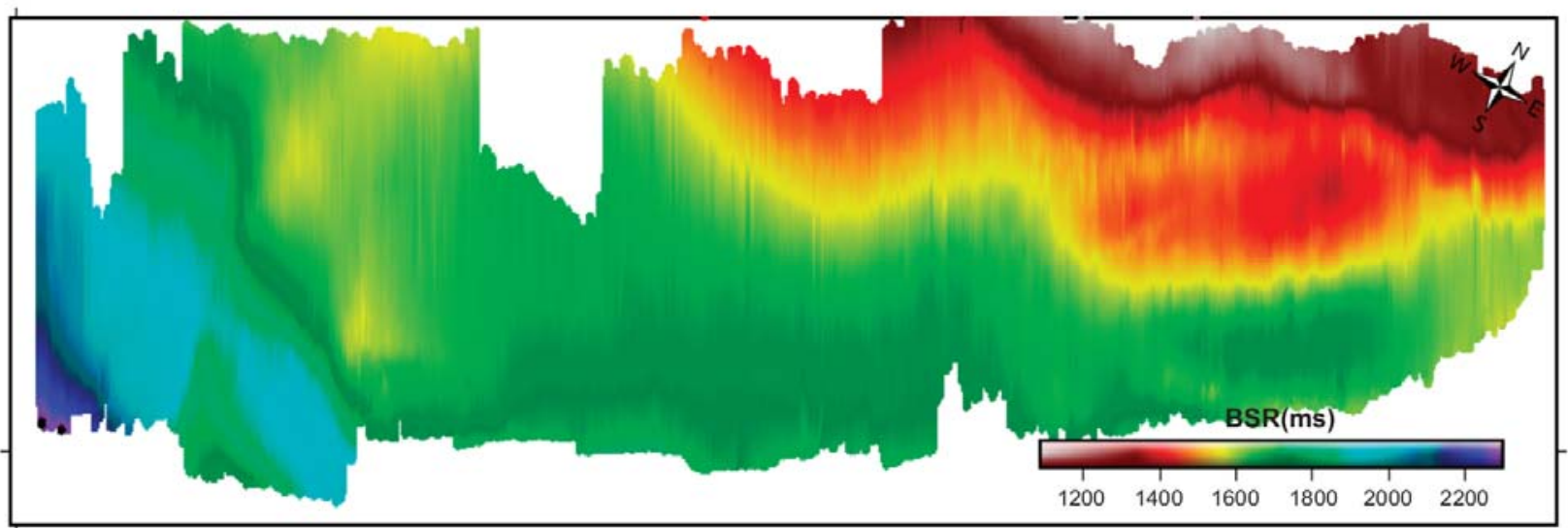

Fig-5
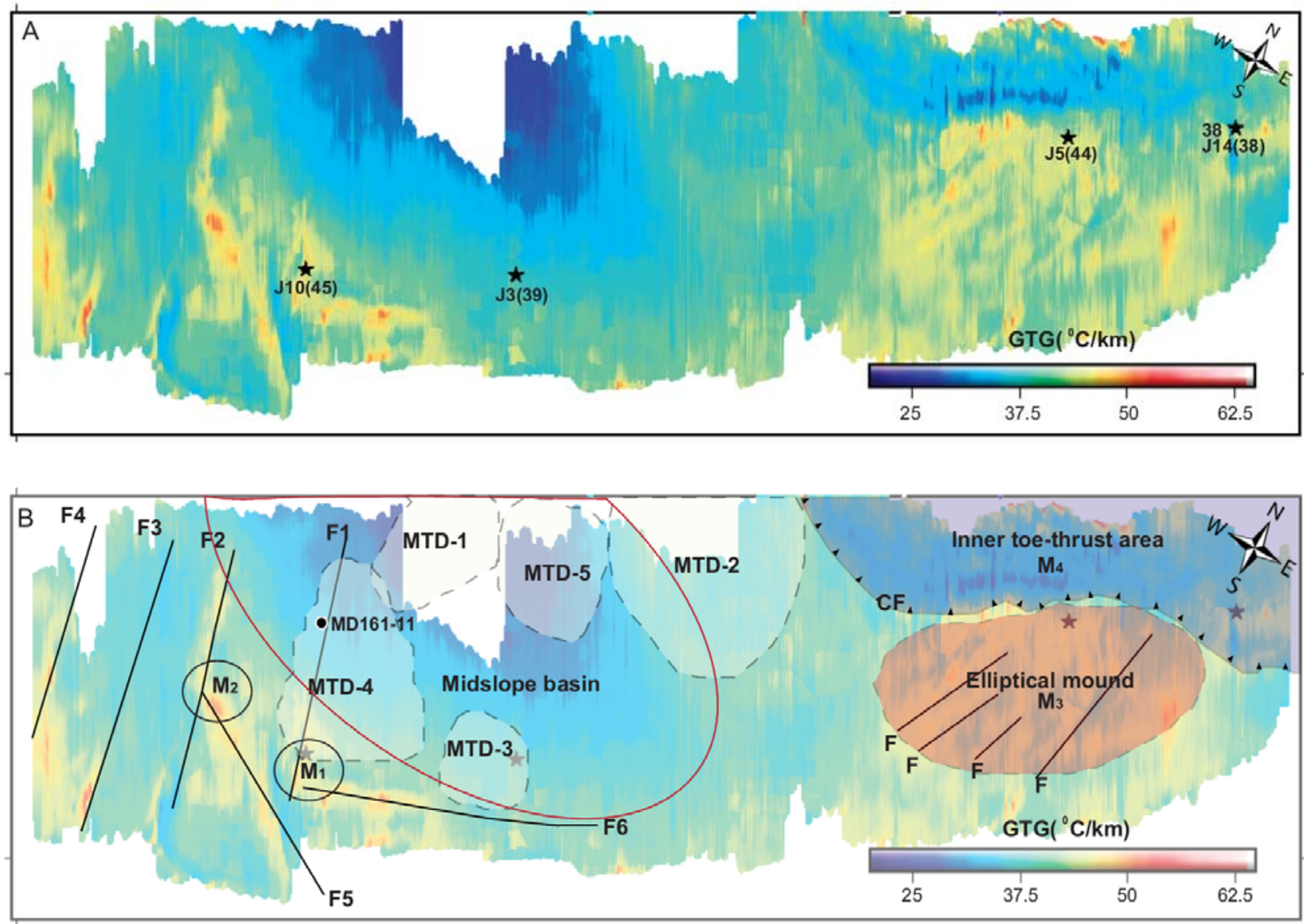

Fig-6 


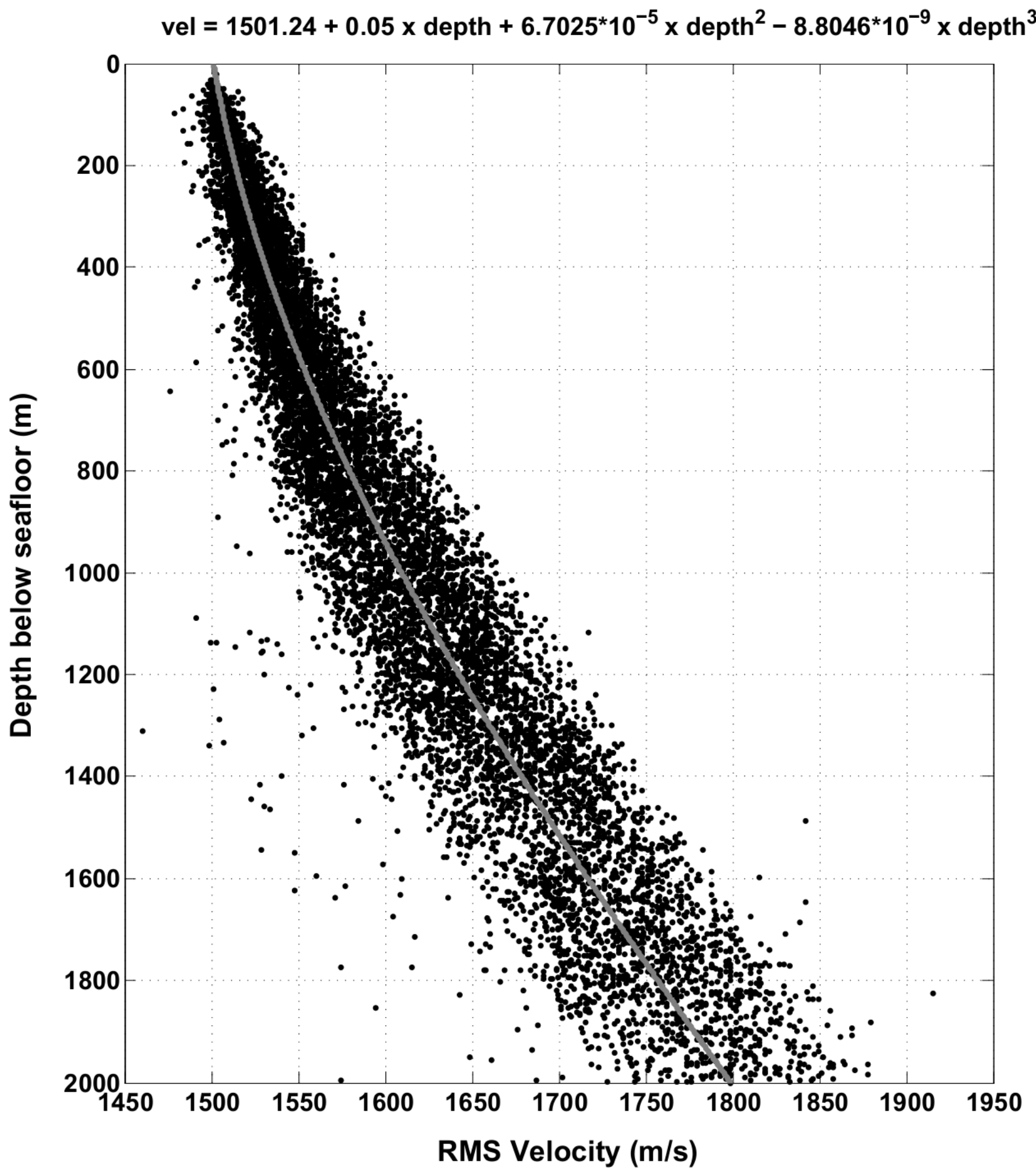

Figure 7 